\title{
Bayesiaans Denken voor Peuters
}

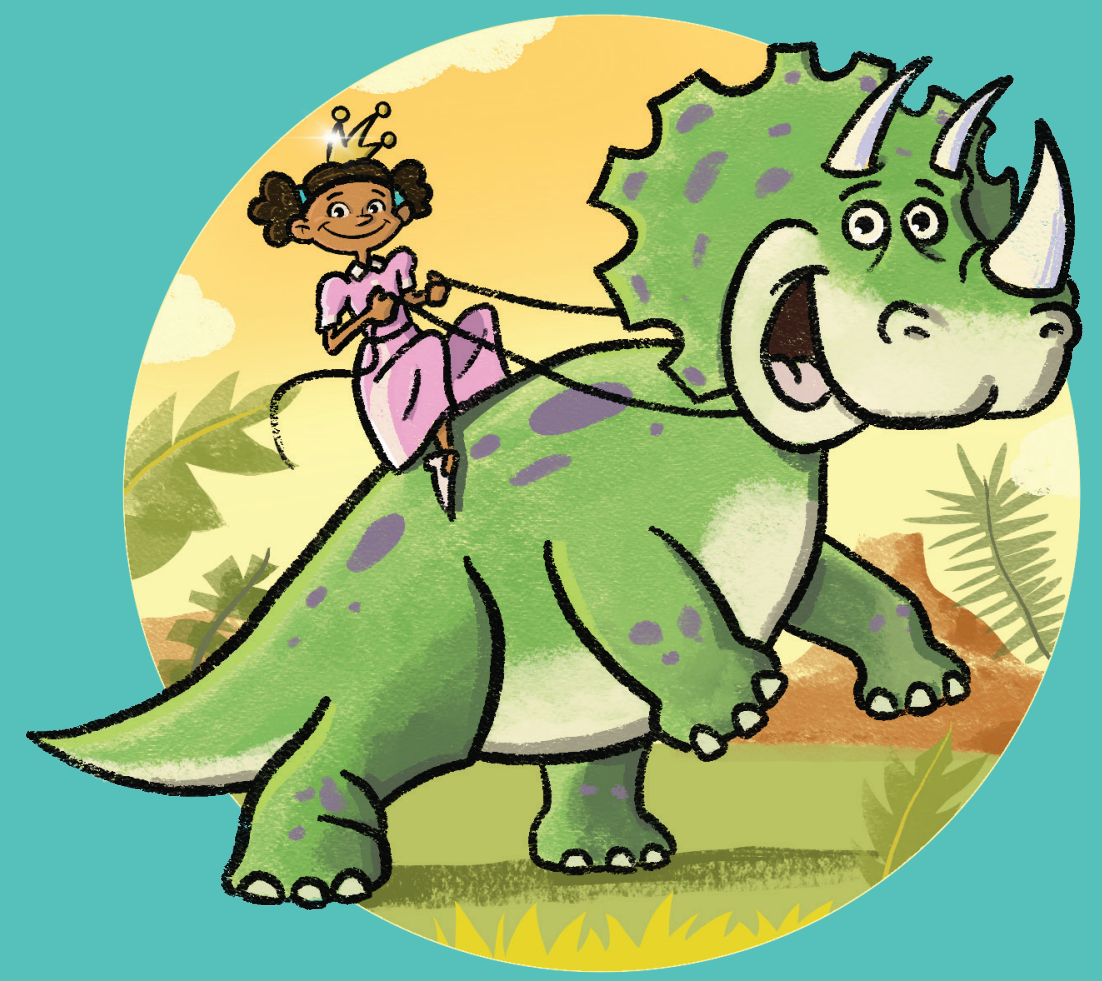

Eric-Jan Wagenmakers Illustraties door Viktor Beekman 


\section{Bayesiaans Denken voor Peuters}

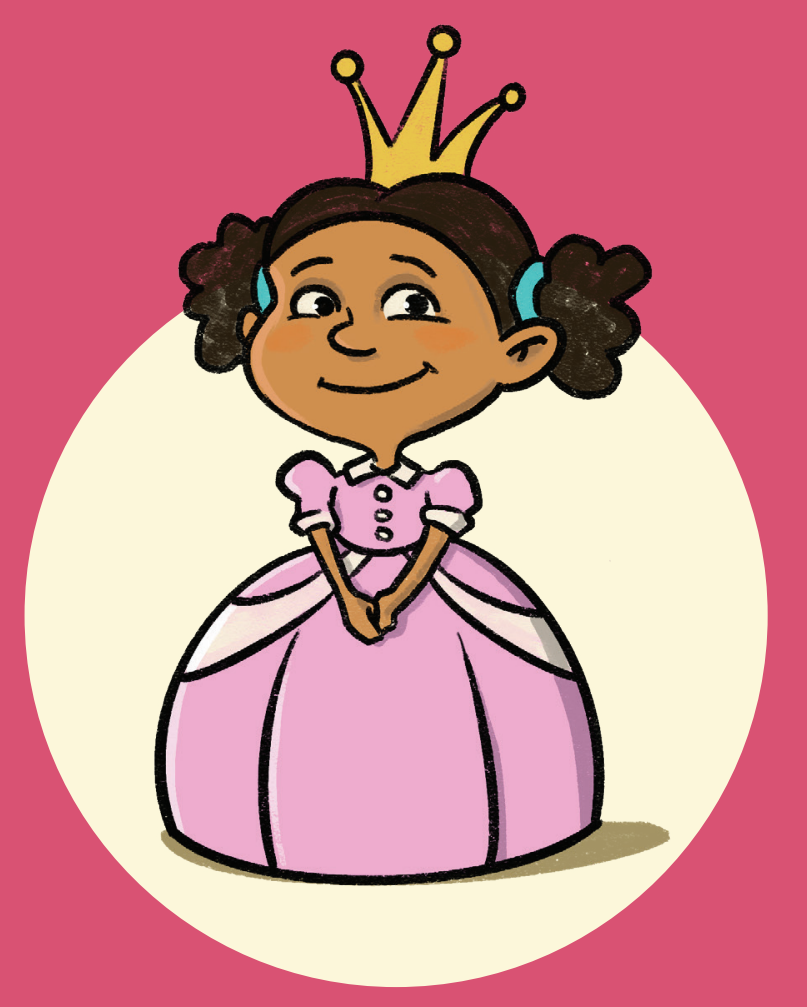

Voor Theo en Leanne 
In een land hier heel ver vandaan zijn Karin en Marieke aan het opscheppen over hoeveel ze wel niet weten van dinosaurussen...

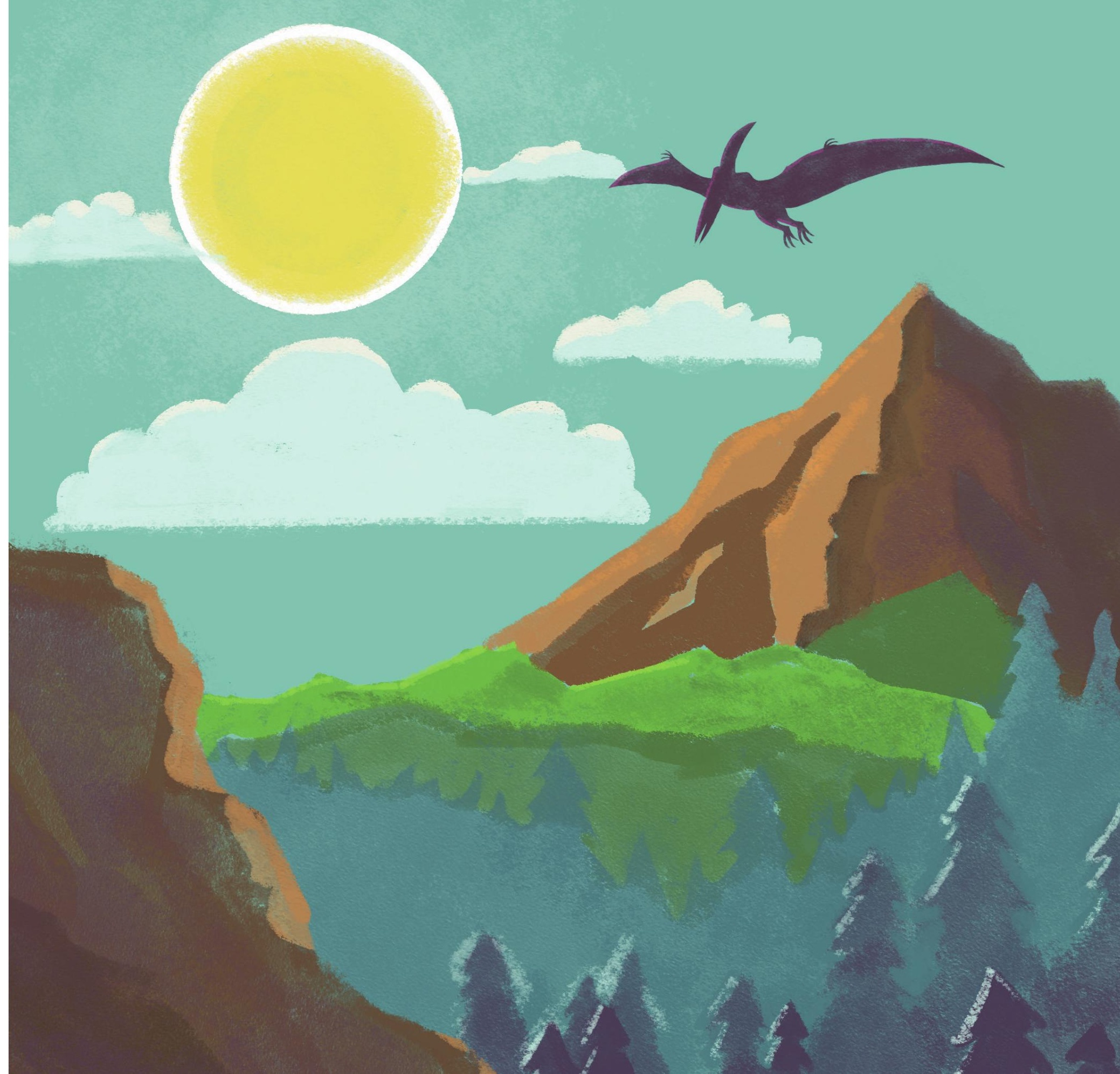




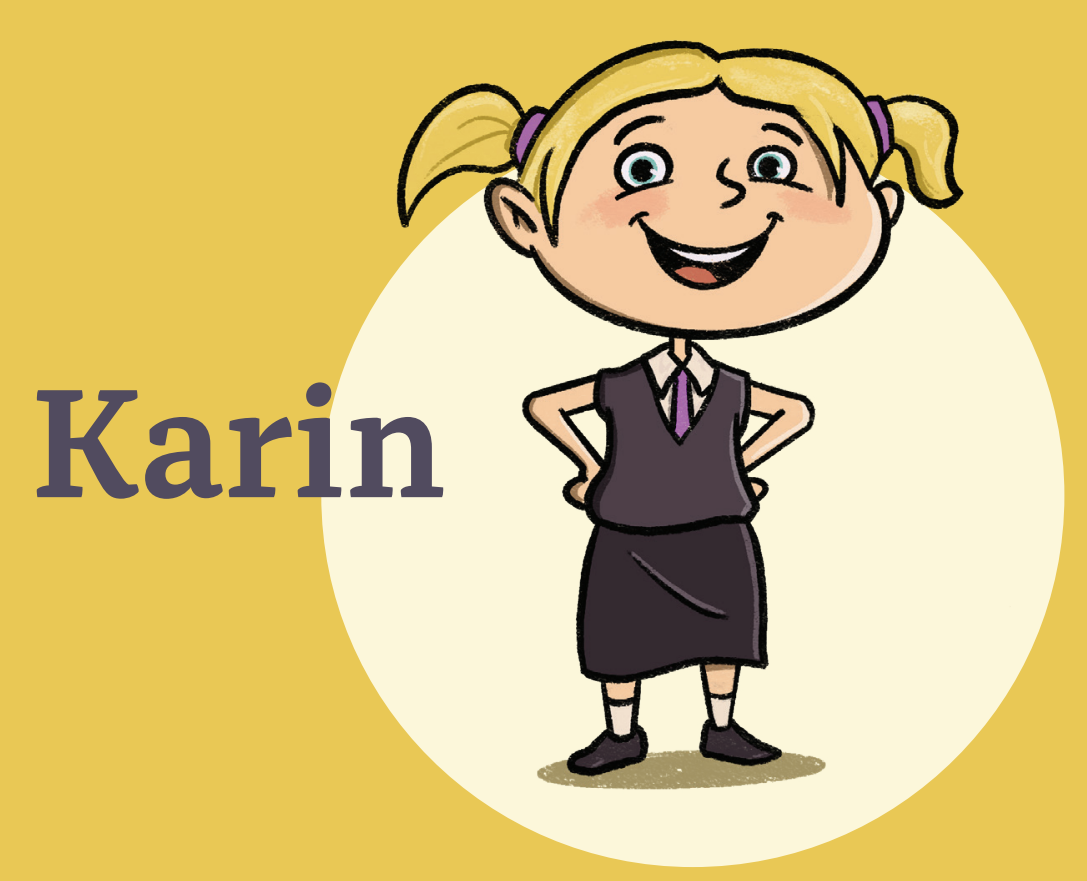

'Ik weet de naam van elke dinosaurus! En ik kan heel snel "Huehuecanauhtlus" zeggen.'

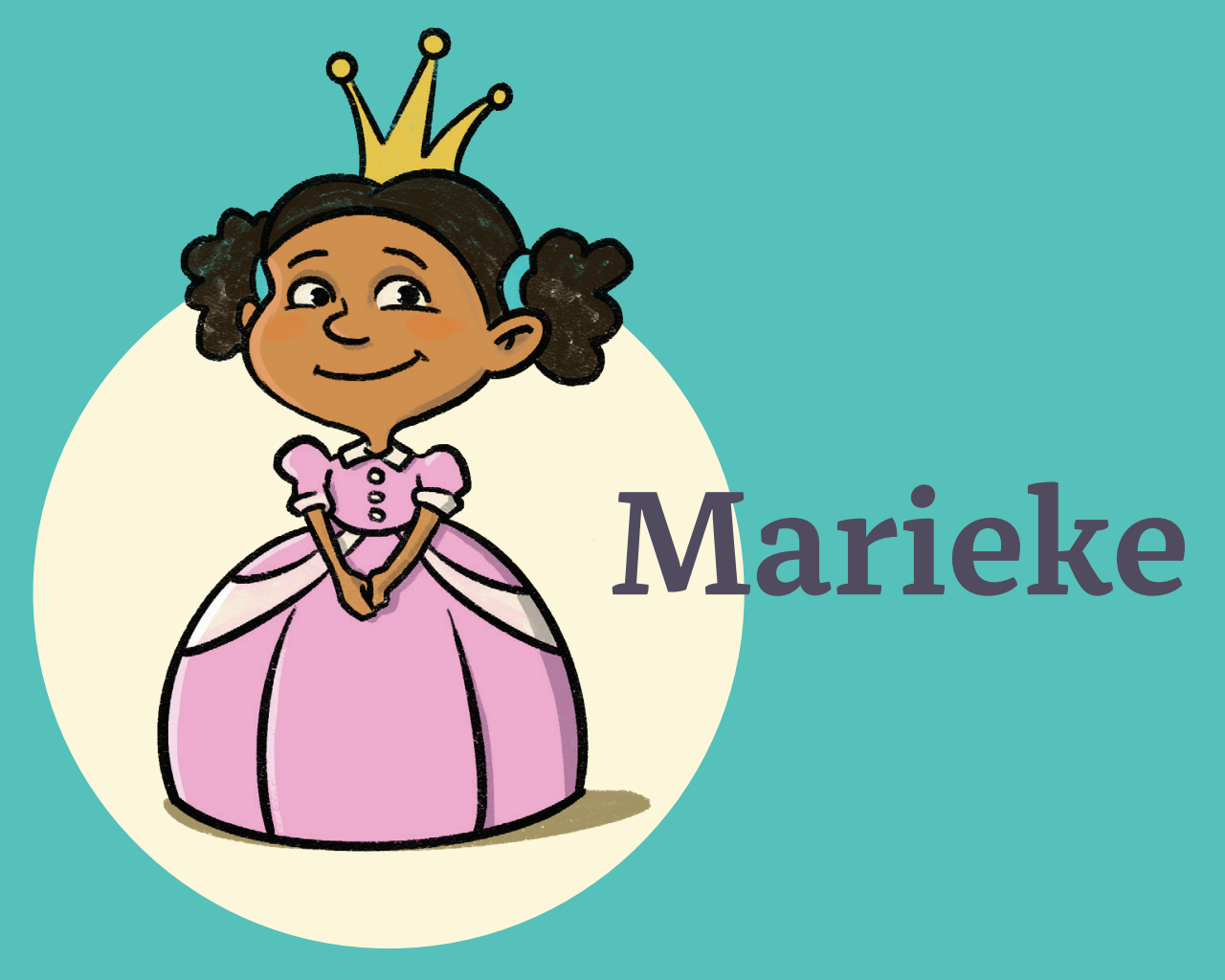

'Ik draag een kroon! En ik kijk veel televisie. Als ik een dinosaurus wil dan koopt mijn papa er gewoon eentje voor mij.' 
Wie het meeste weet over

dinosaurussen krijgt 14 zelfgebakken koekjes van tante Truus.

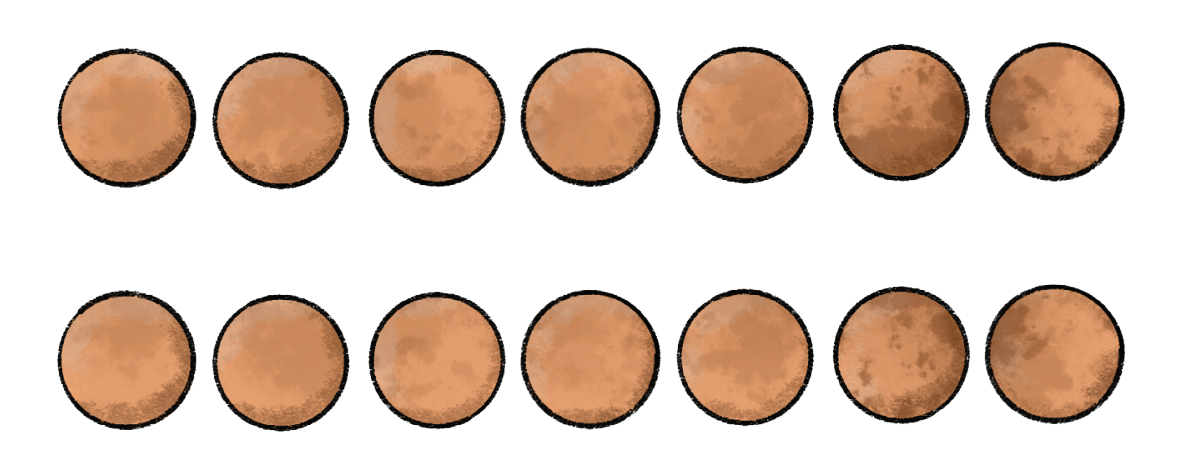


Tante Truus heeft geen idee of Karin of Marieke nu het meeste weet over dinosaurussen, dus wil ze de koekjes gelijk verdelen.

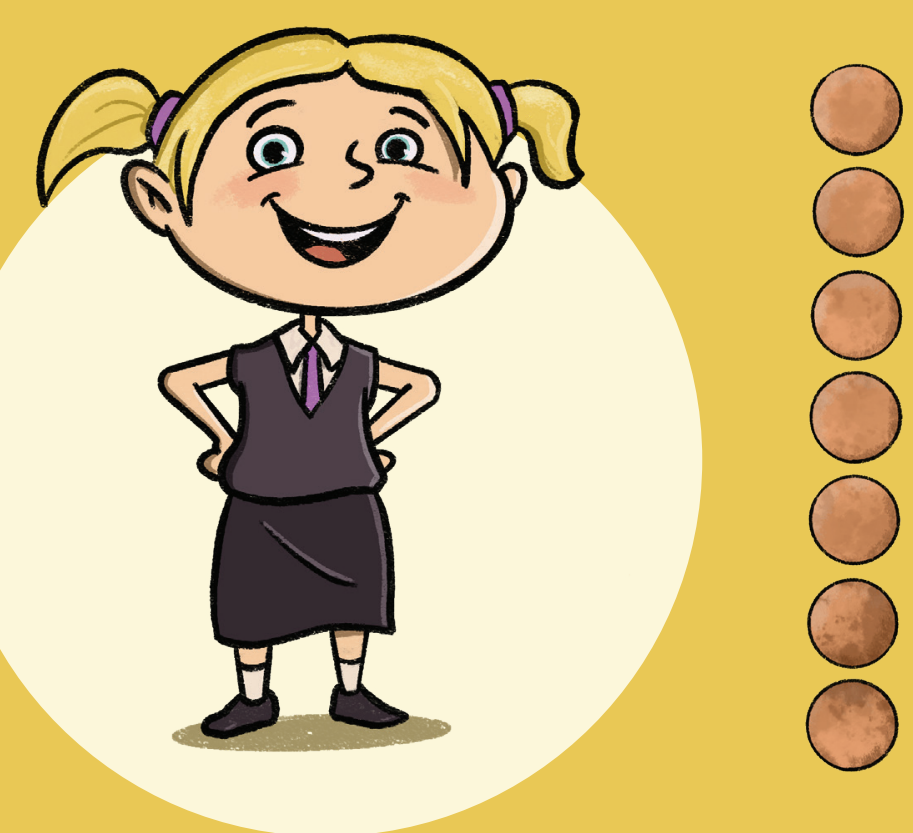

8
8
8
0

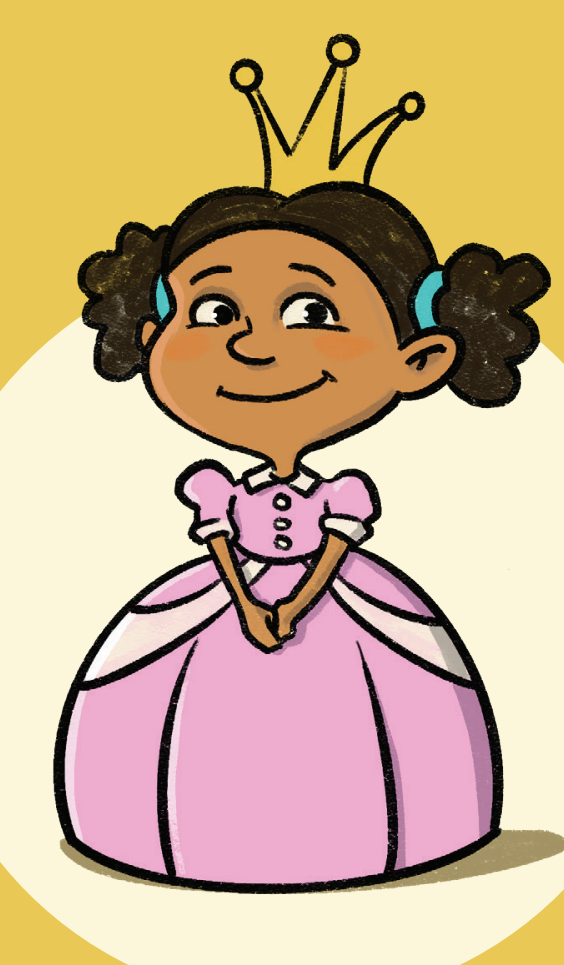


Maar wacht eens!

Tante Truus heeft een idee.

Ze gaat een vraag stellen om zo te bepalen wie het meeste weet over dinosaurussen.

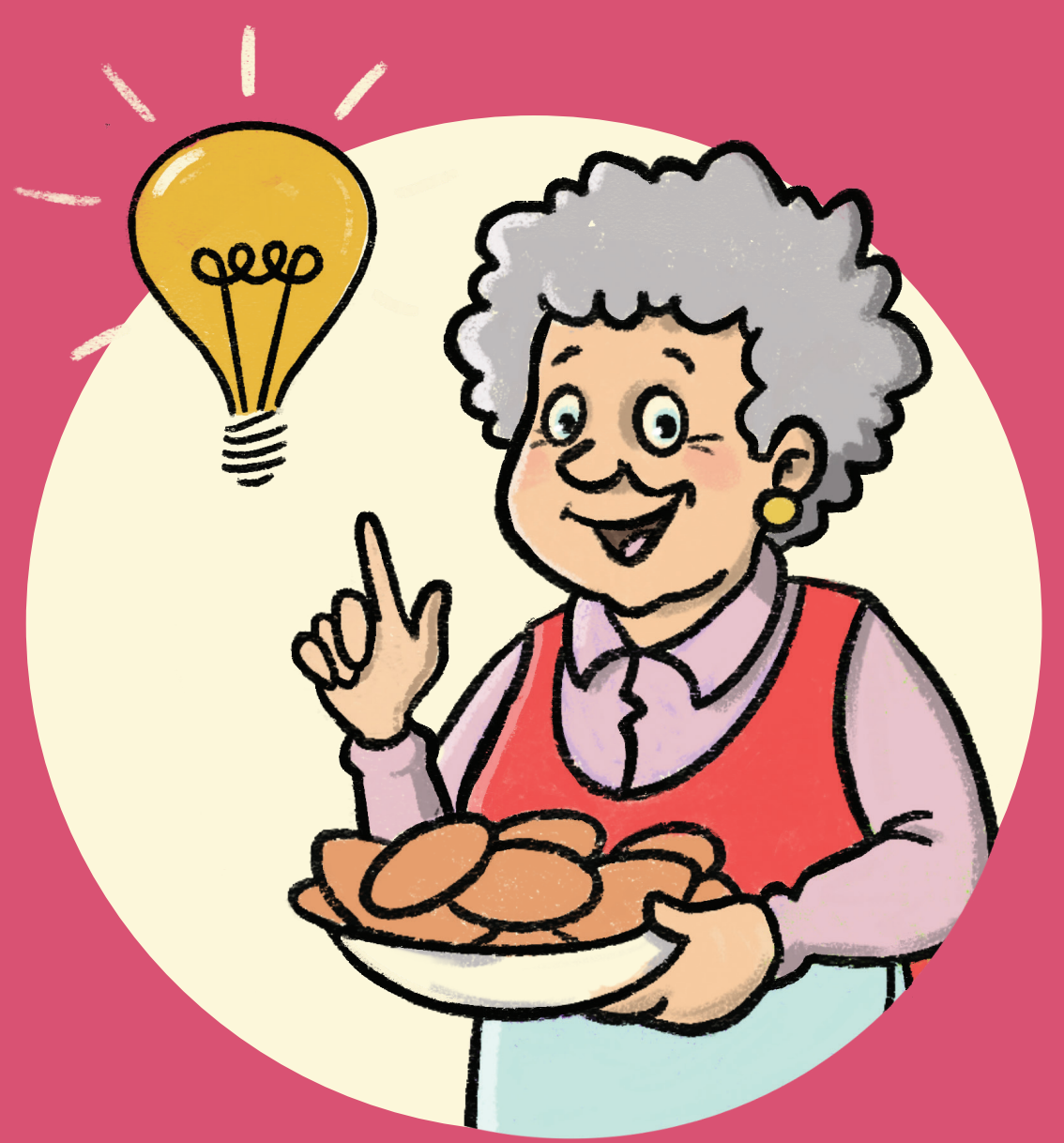




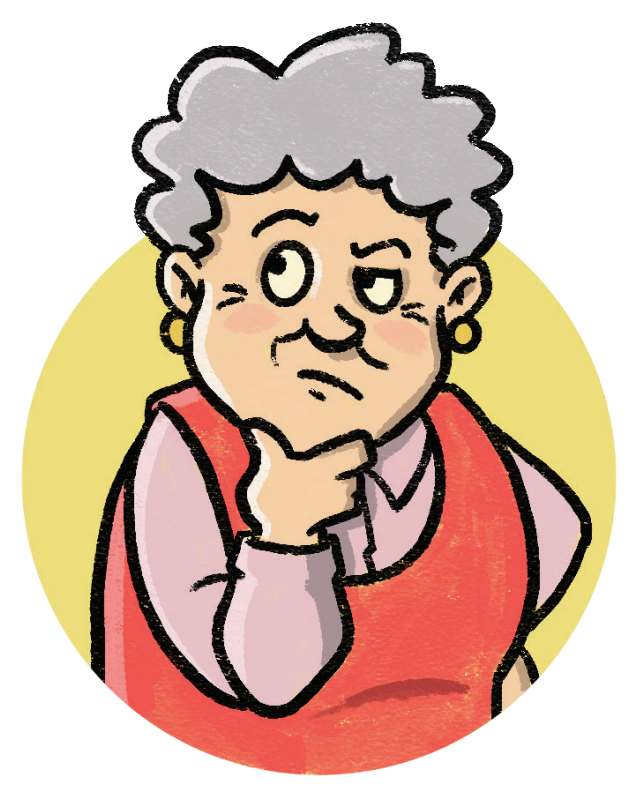

De vraag is:

'Hoeveel hoorns heeft een Triceratops op zijn kop?'

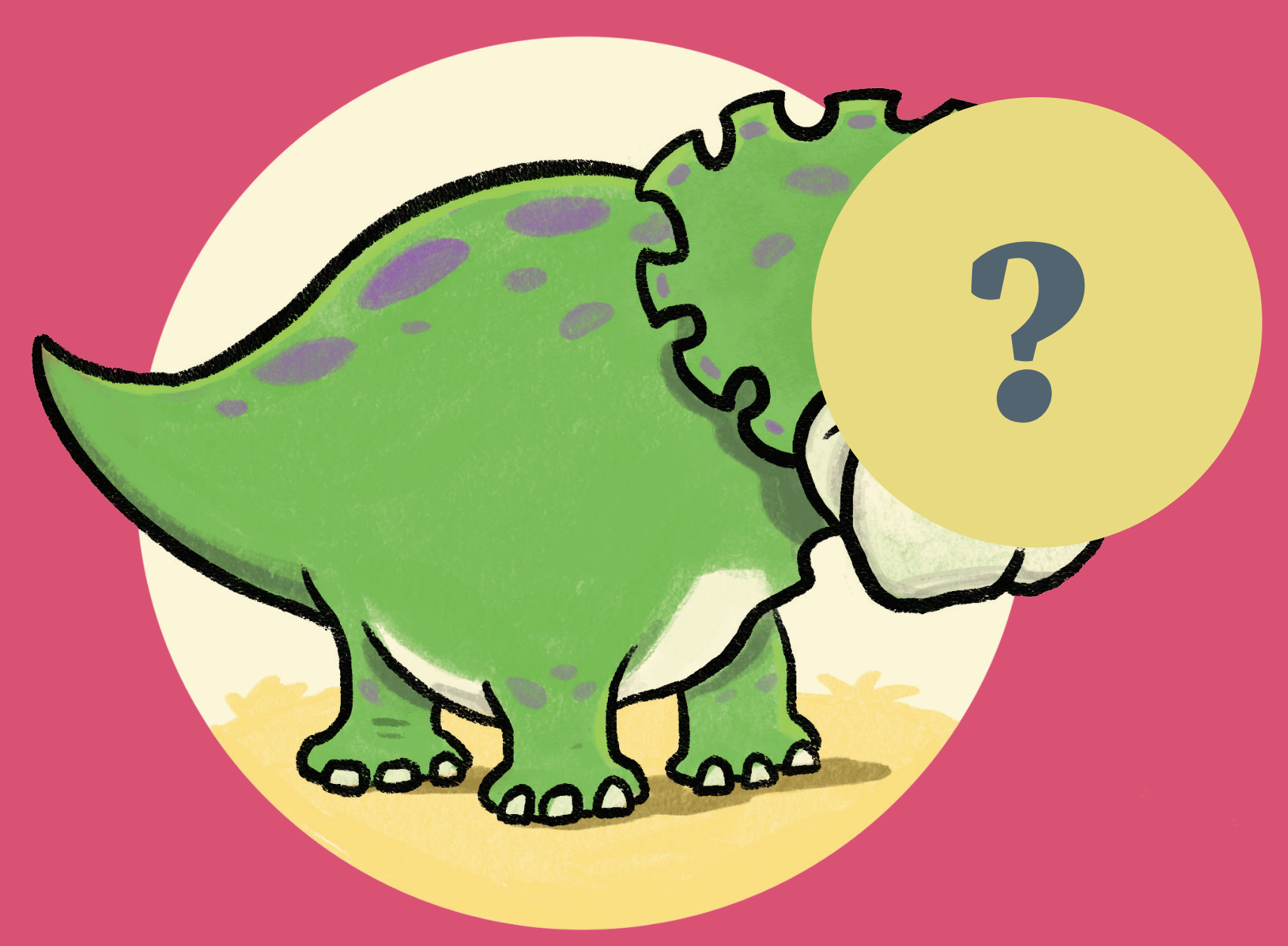




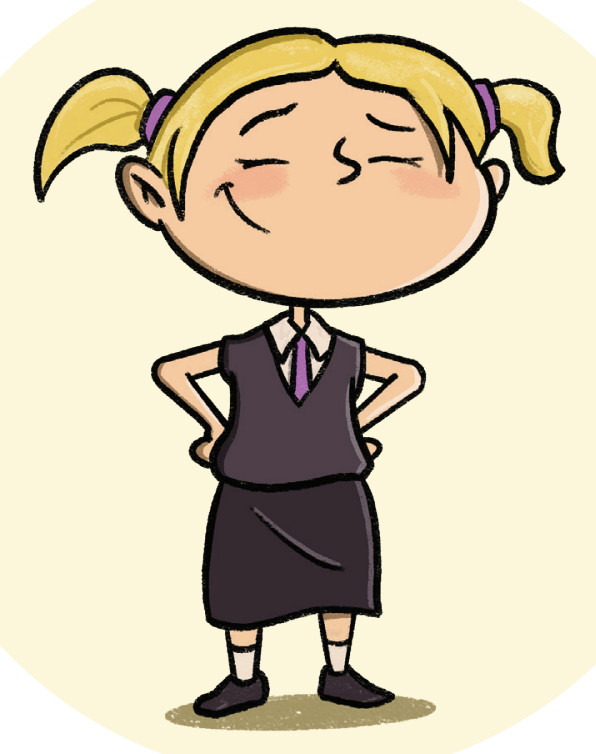

'Drie! Zeker weten!'

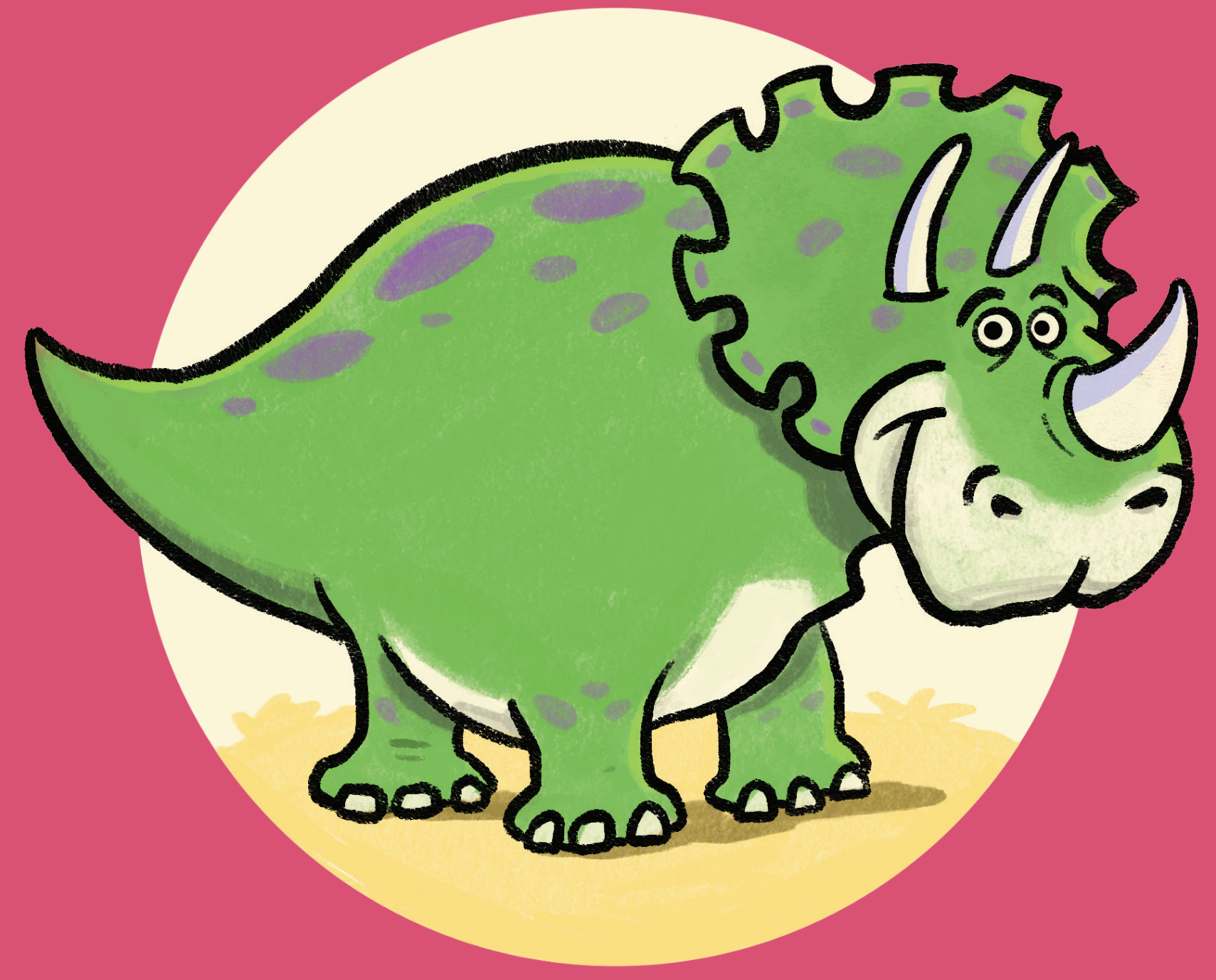

$-16-$ 


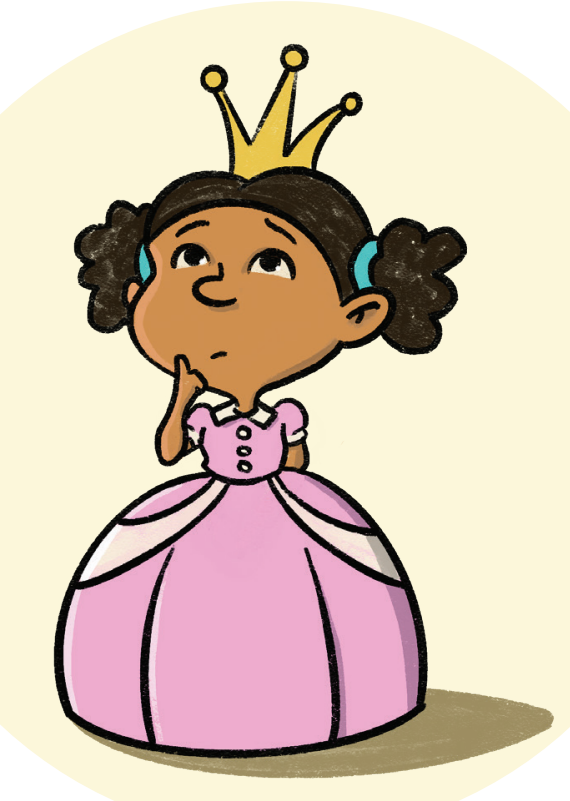

'Oei, dit is moeilijk! Ik weet het niet zeker. Het zou nul kunnen zijn, of één, of twee, of drie, of vier, of vijf - iedere mogelijkheid lijkt me even waarschijnlijk!'

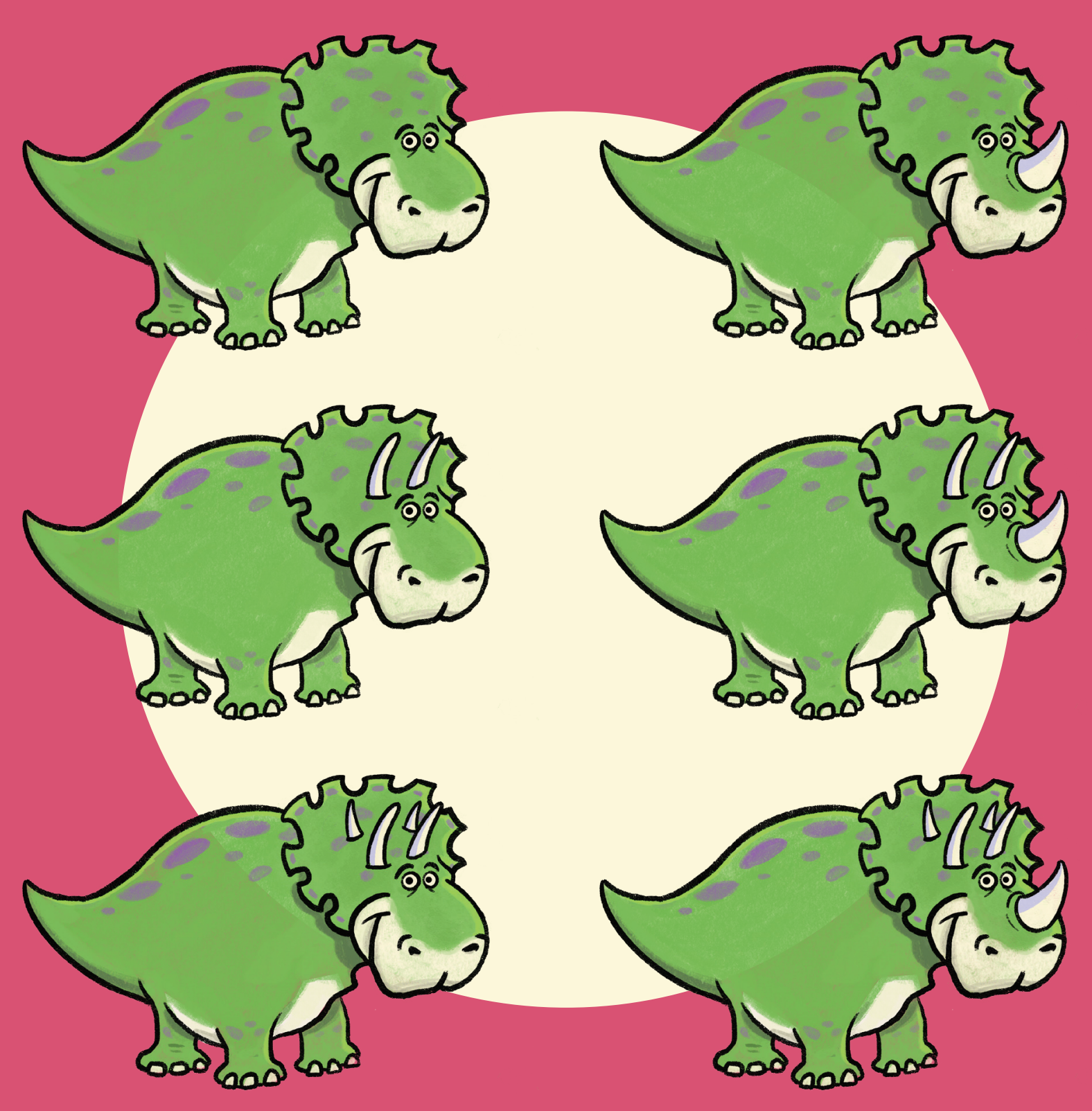

$-19-$ 


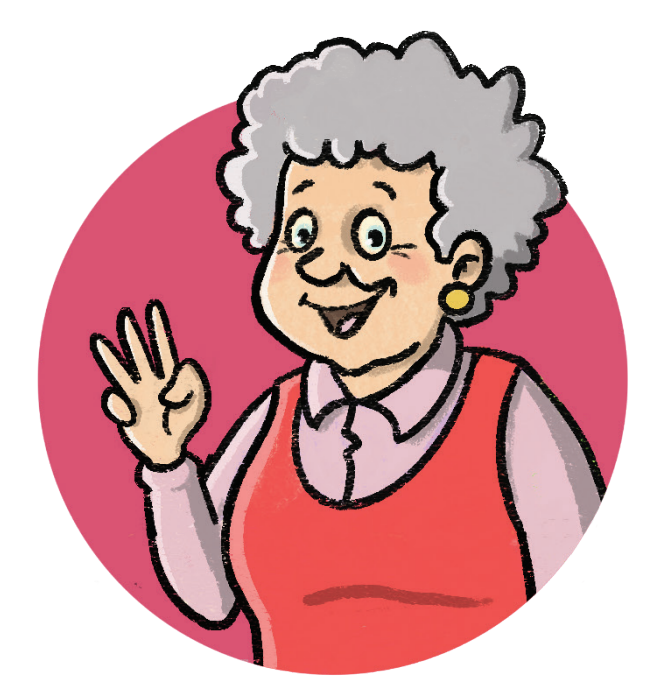

'Het juiste antwoord is drie.

Een Triceratops heeft drie hoorns op zijn kop.'

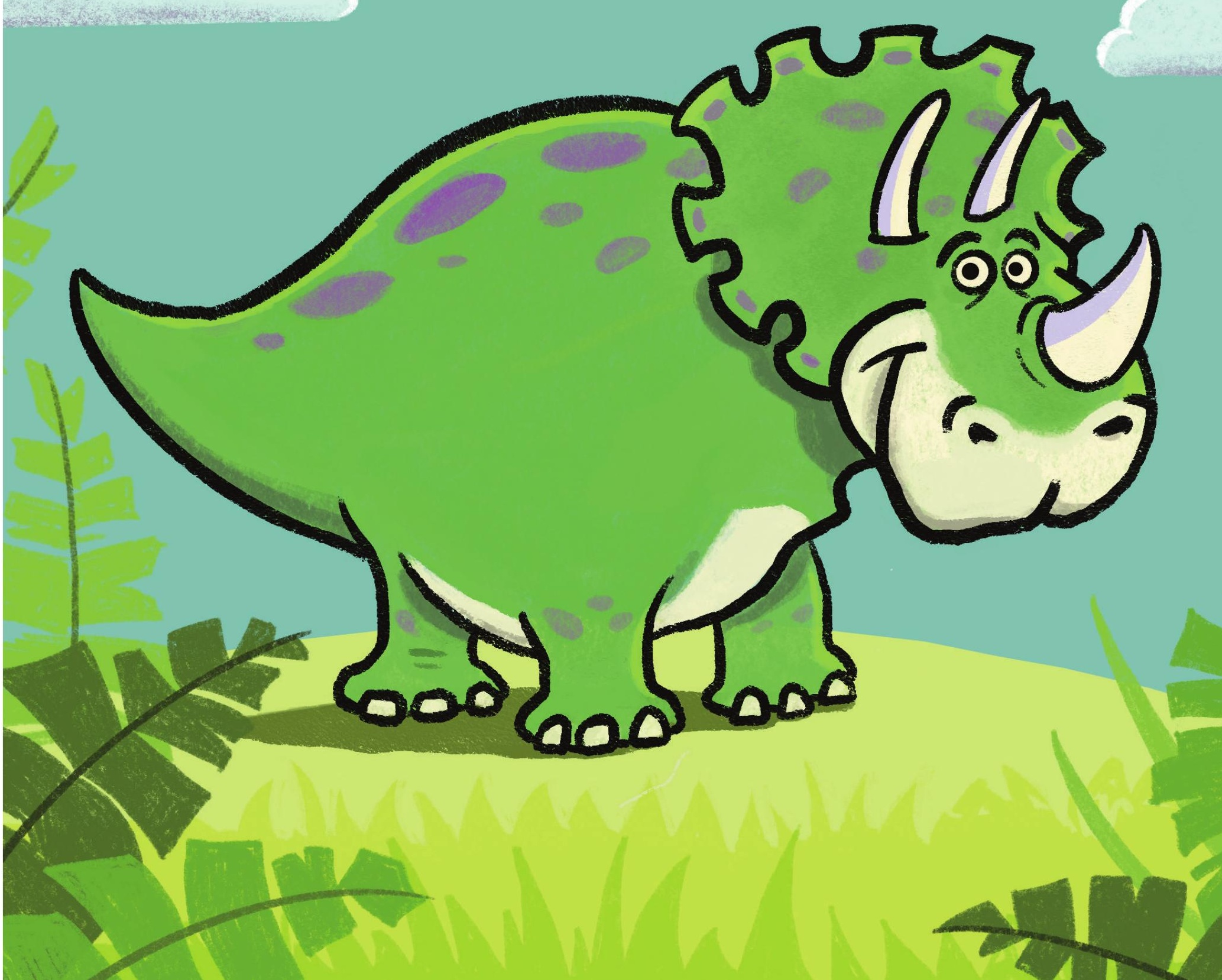


Hoe goed hebben Karin en Marieke het juiste antwoord voorspeld?

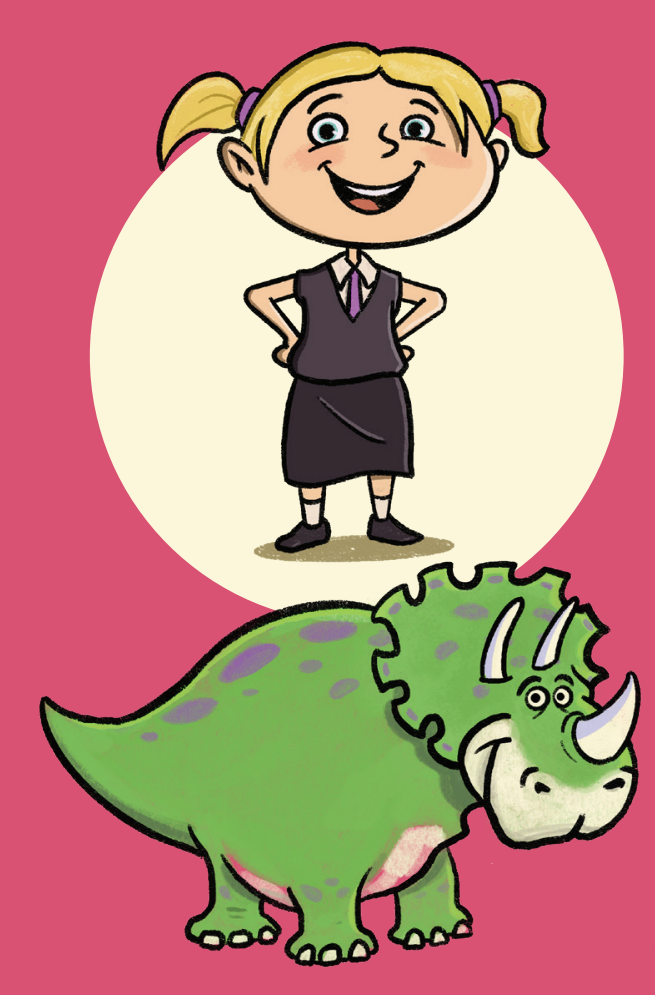

Helemaal goed!

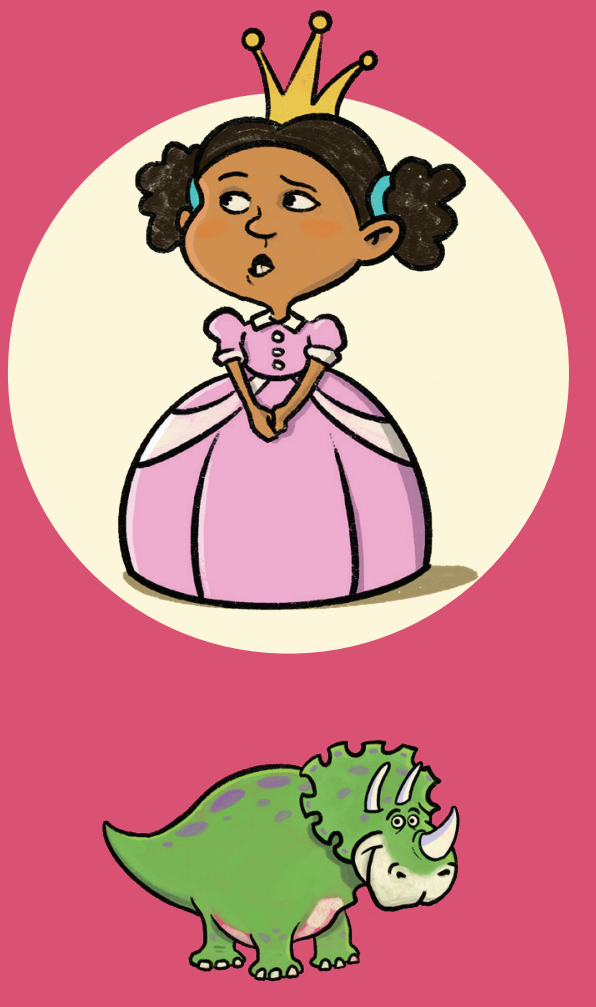

Eén van haar zes voorspellingen is juist!
Karin voorspelde zes keer beter dan Marieke. Daarom wil Tante Truus Karin nu zes keer zoveel koekjes geven als Marieke.
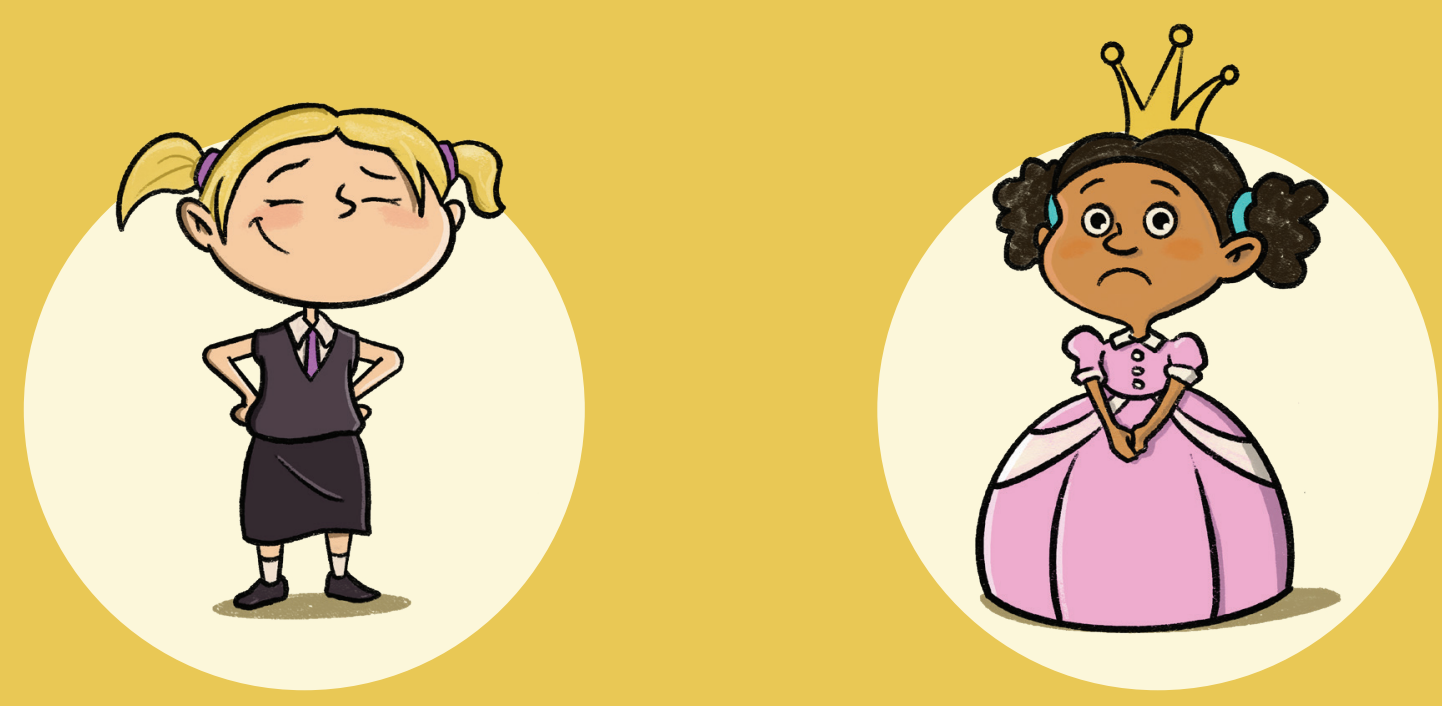

000000 
Maar wacht eens! Tante Truus heeft nog een idee. Ze gaat een tweede vraag over dinosaurussen stellen. Ben je er klaar voor?

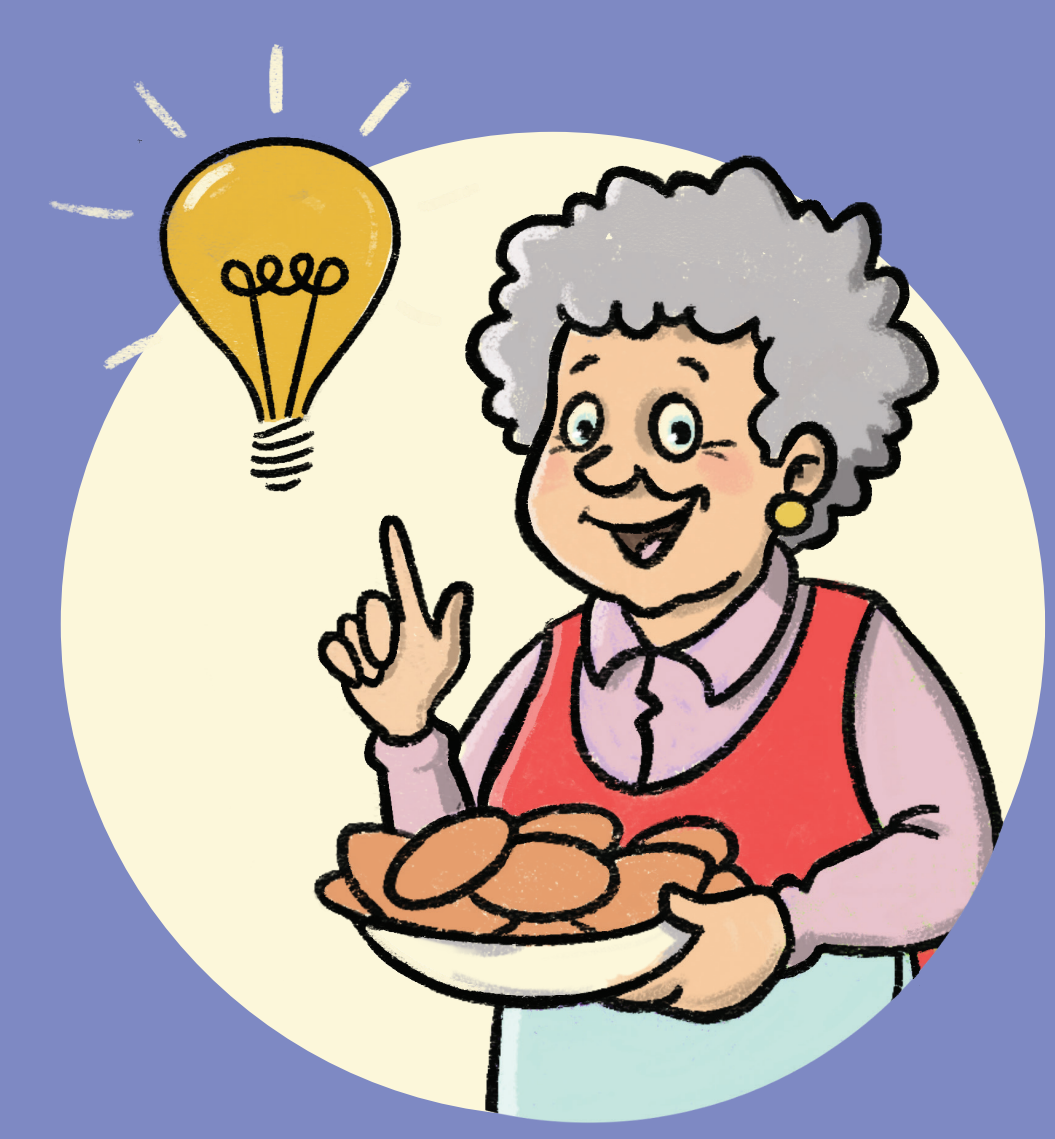




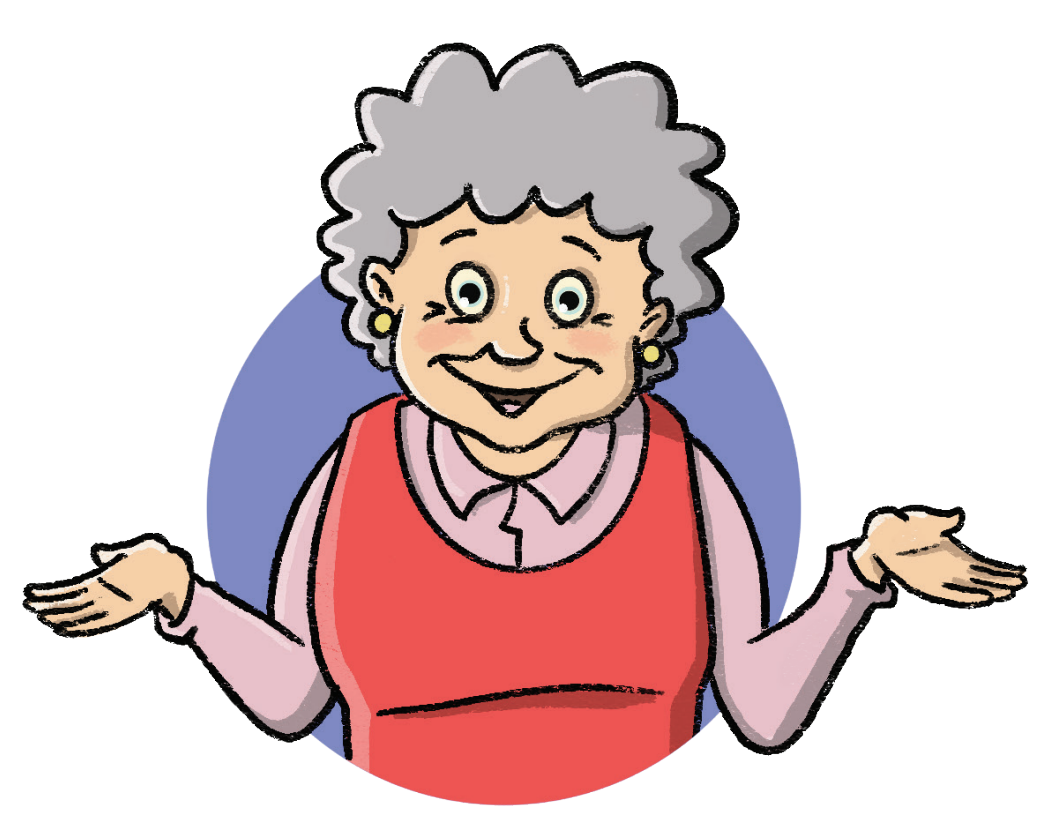

De tweede vraag is:

'Hoeveel stekels heeft een

Stegosaurus aan zijn staart?'

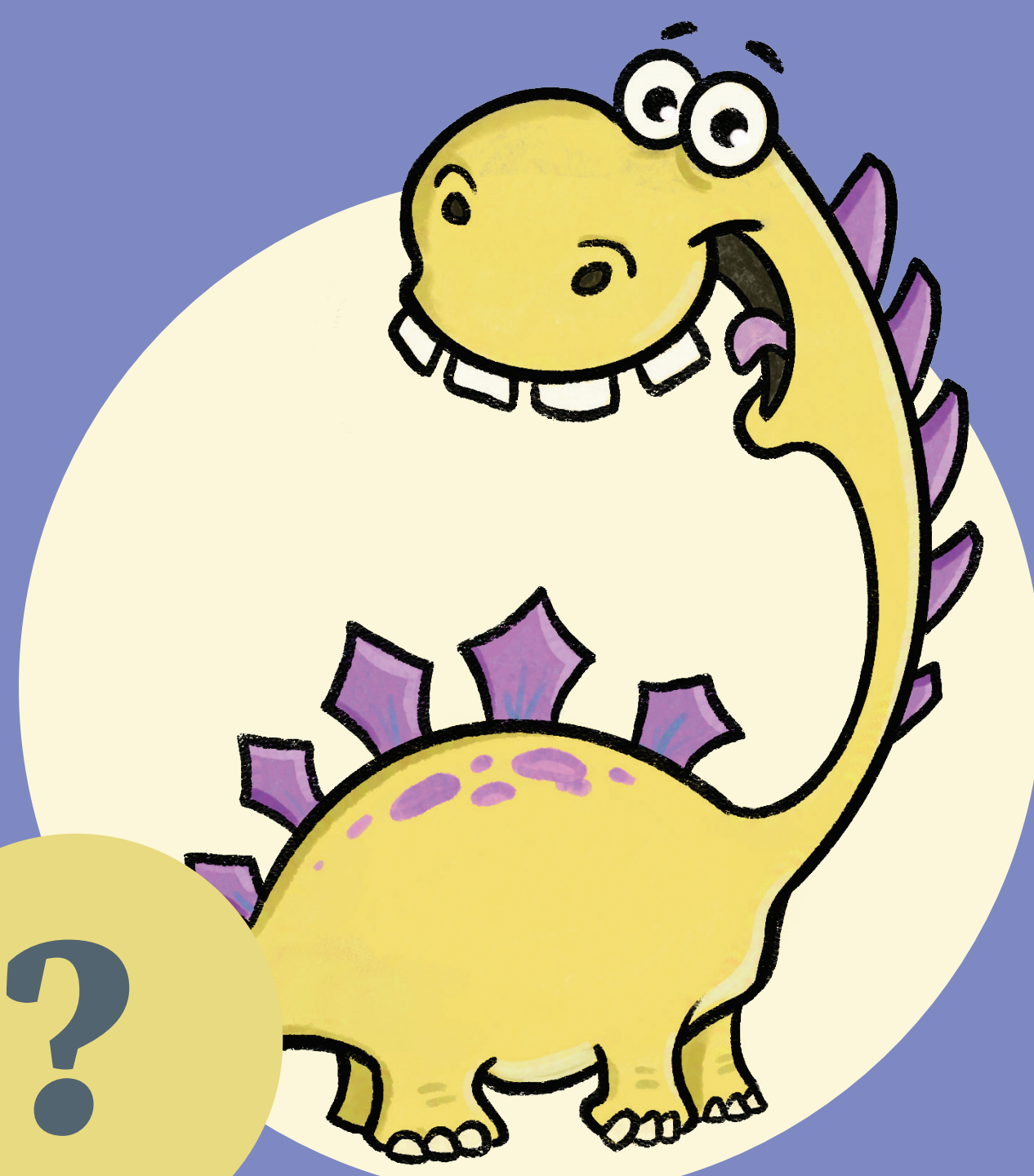

$-27-$ 


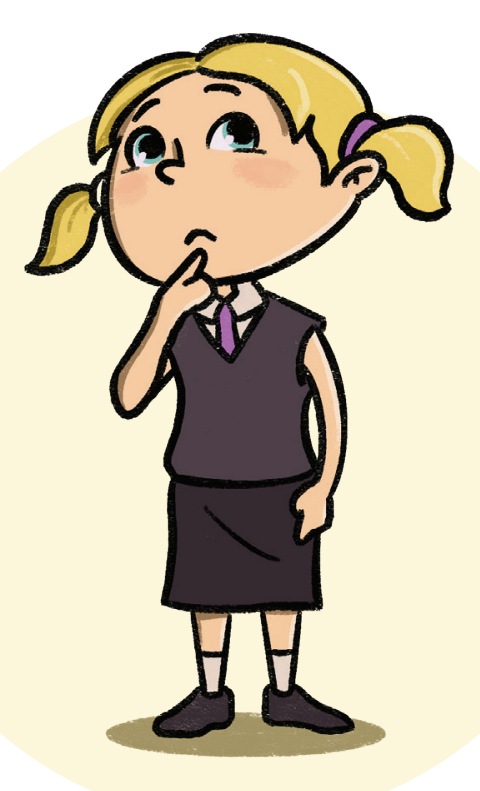

'Hmmm. Ik twijfel een beetje. Vier of zes stekels - beide mogelijkheden lijken me even waarschijnlijk.'

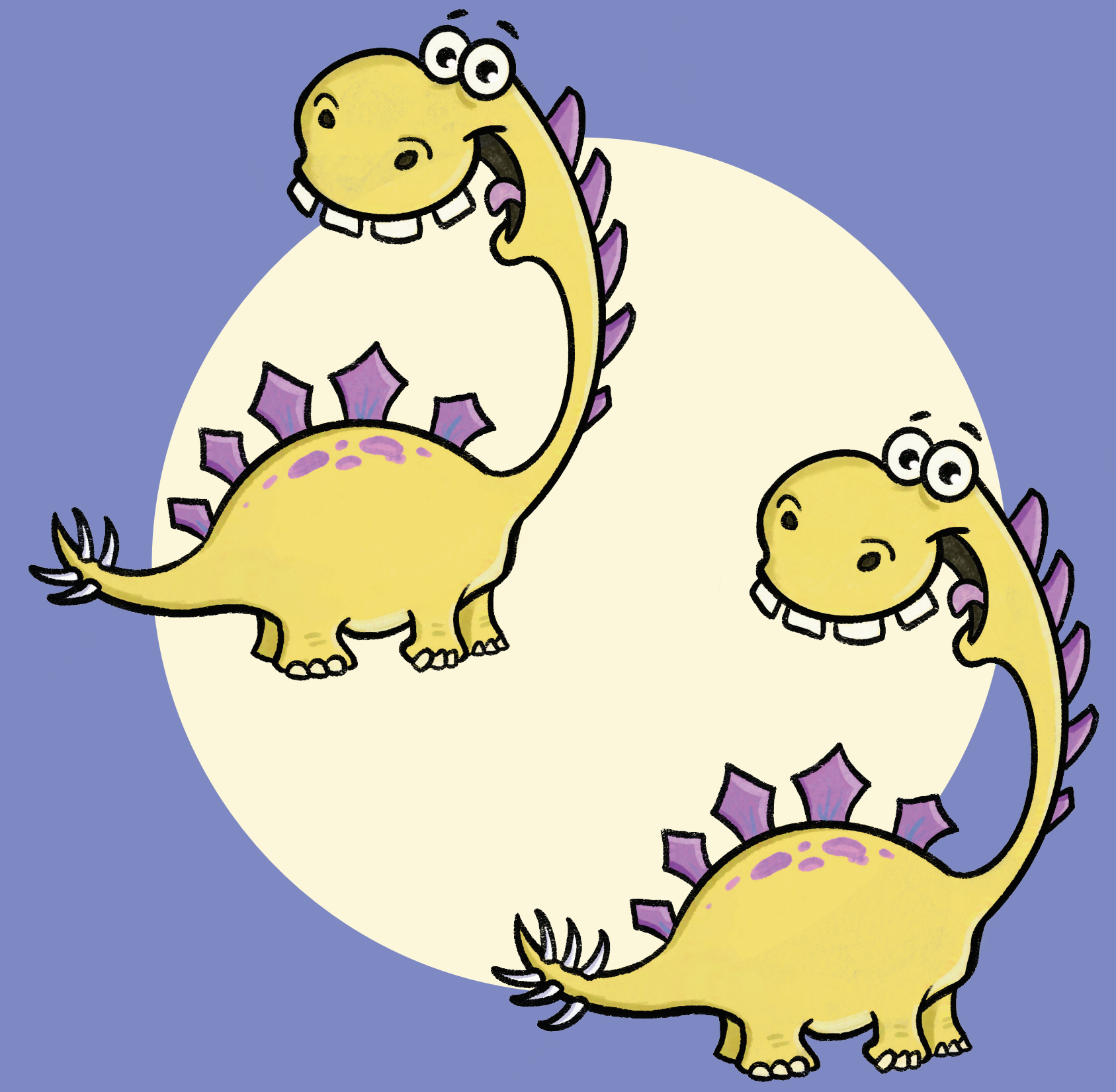

$-29-$ 


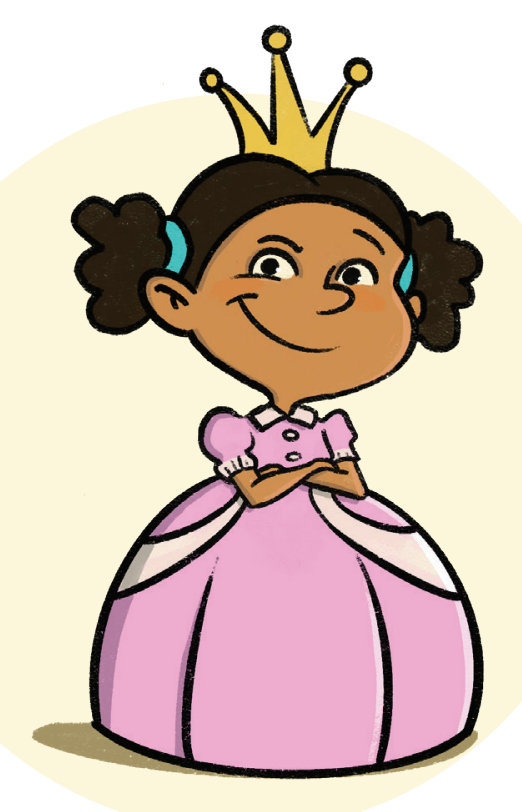

'Vier! Die was makkelijk!'

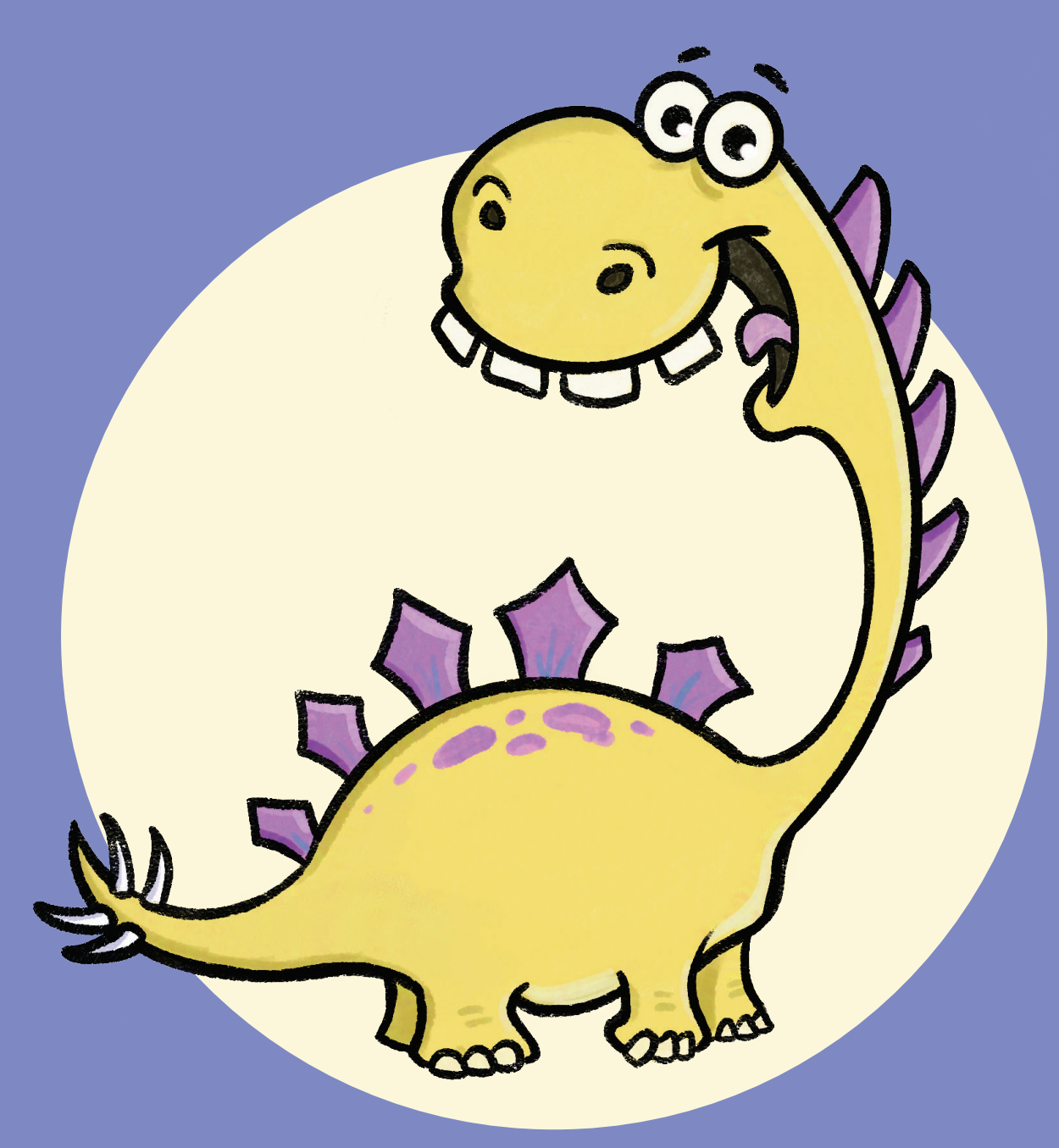

$-31-$ 


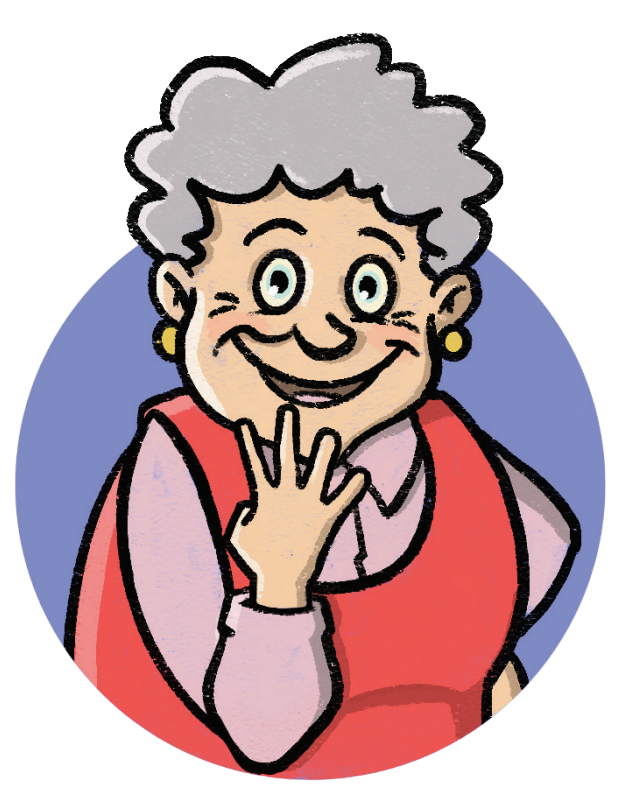

'Het juiste antwoord is vier.

Een Stegosaurus heeft vier stekels aan zijn staart.'

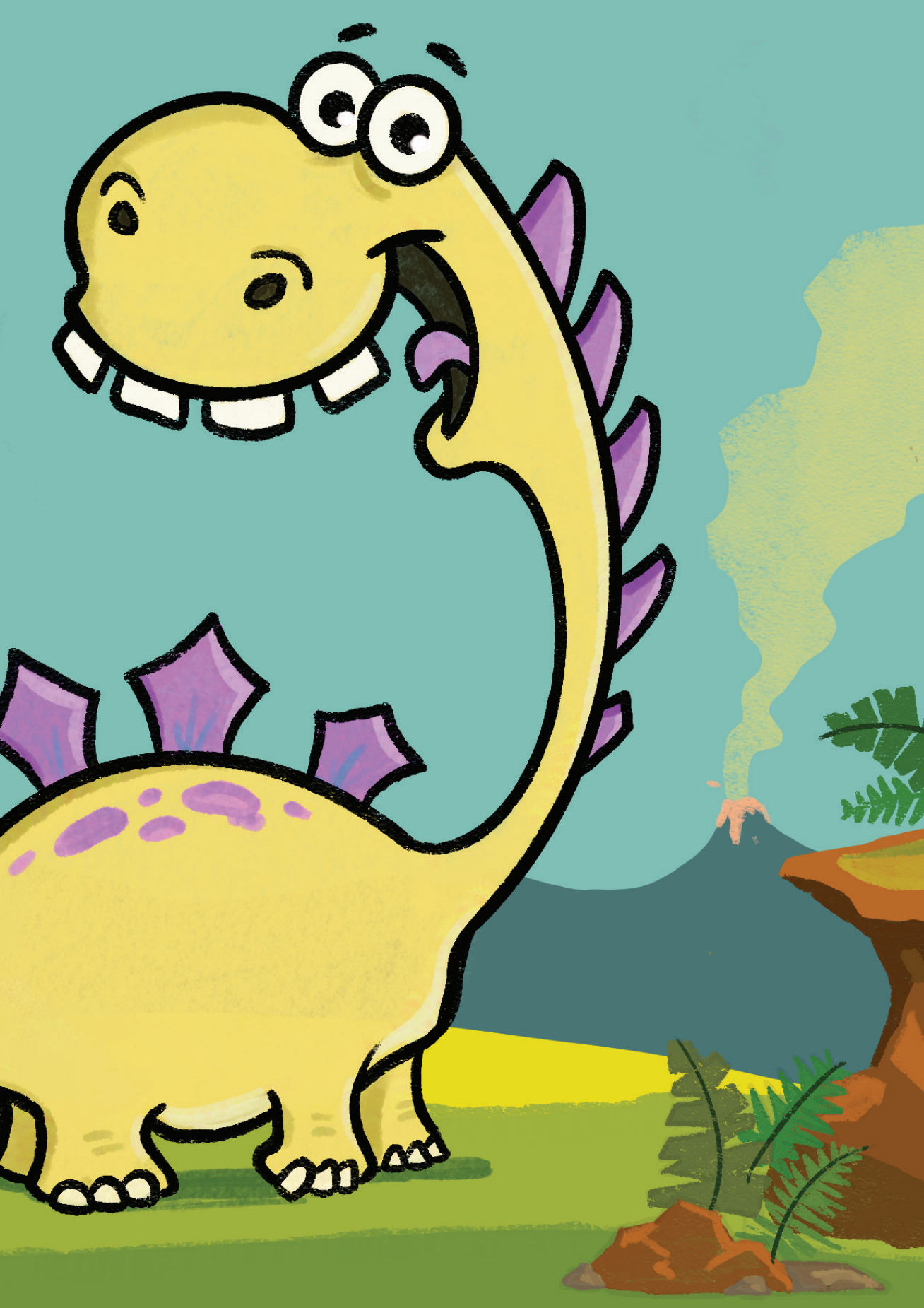


Hoe goed hebben Karin en Marieke het juiste antwoord voorspeld?
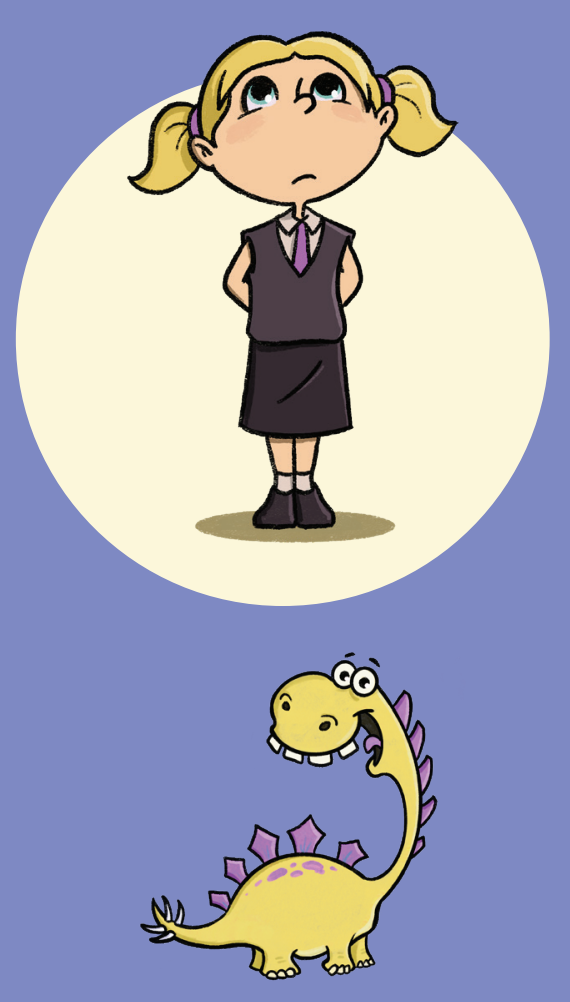

Eén van haar twee voorspellingen is juist!

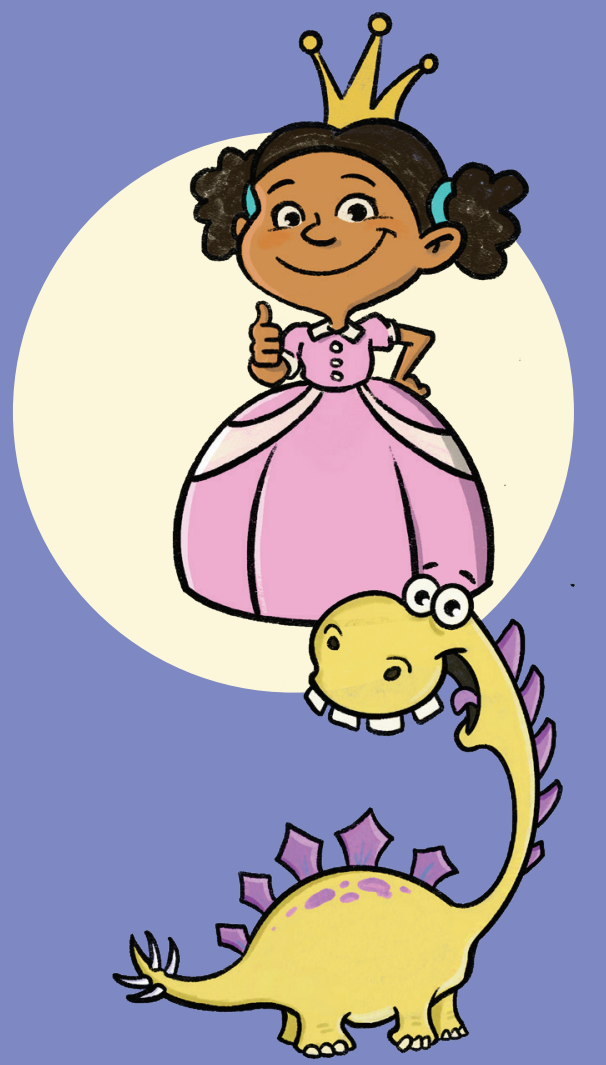

Helemaal goed!
Op de Triceratops vraag deed Karin het zes keer beter dan Marieke.
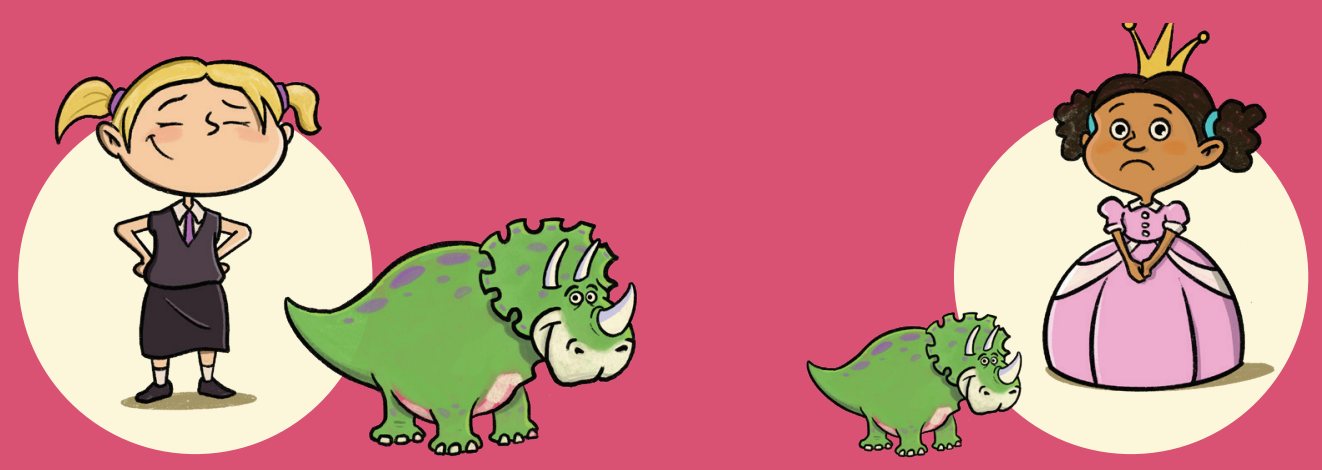

Op de Stegosaurus vraag deed Marieke het twee keer beter dan Karin.

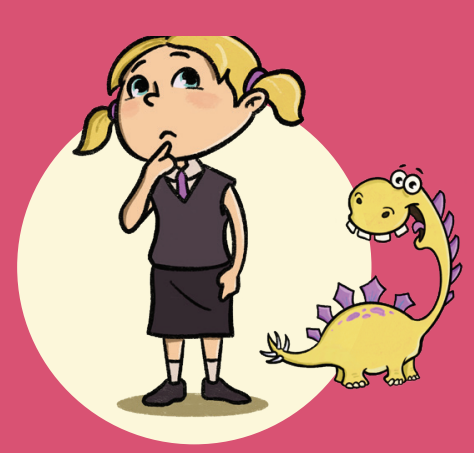


In totaal deed Karin het dus $6 / 2=3$ keer beter dan Marieke. Gebaseerd op deze kennis vindt tante Truus dat Karin drie keer zoveel koekjes verdient als Marieke.

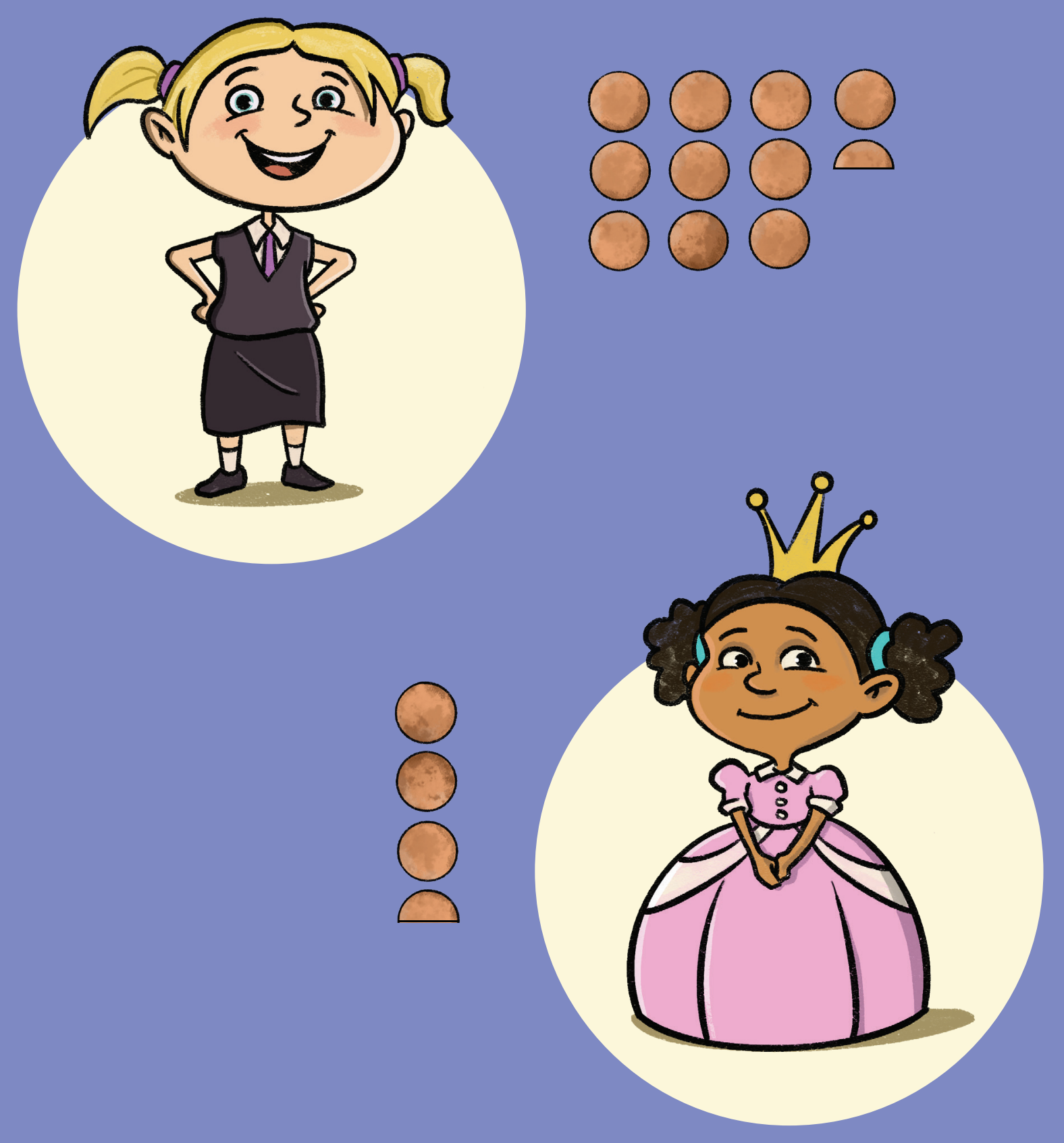




\section{Peuters, wat hebben we geleerd?}

1 Een Triceratops heeft drie hoorns op zijn kop.

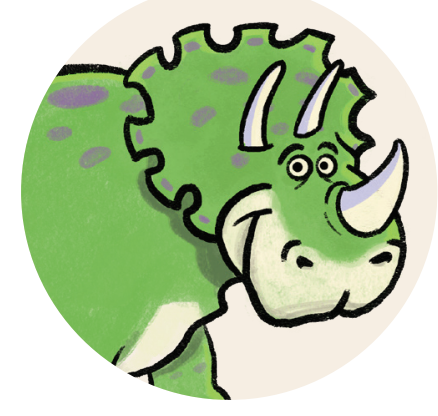

2 Een Stegosaurus heeft vier stekels aan zijn staart.

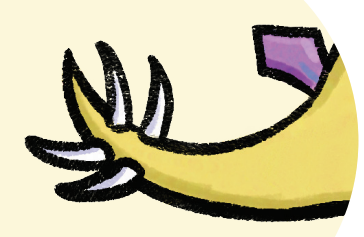

3 Koekjes meten overtuiging
Karin deed het beter dan Marieke op de dinosaurus-test, en daarom denkt tante Truus dat Karin het meeste weet over dinosaurussen - maar tante Truus is niet 100\% zeker.

Dus krijgt Marieke nog steeds wat koekjes, ondanks het feit dat ze het slechter deed op de test dan Karin.

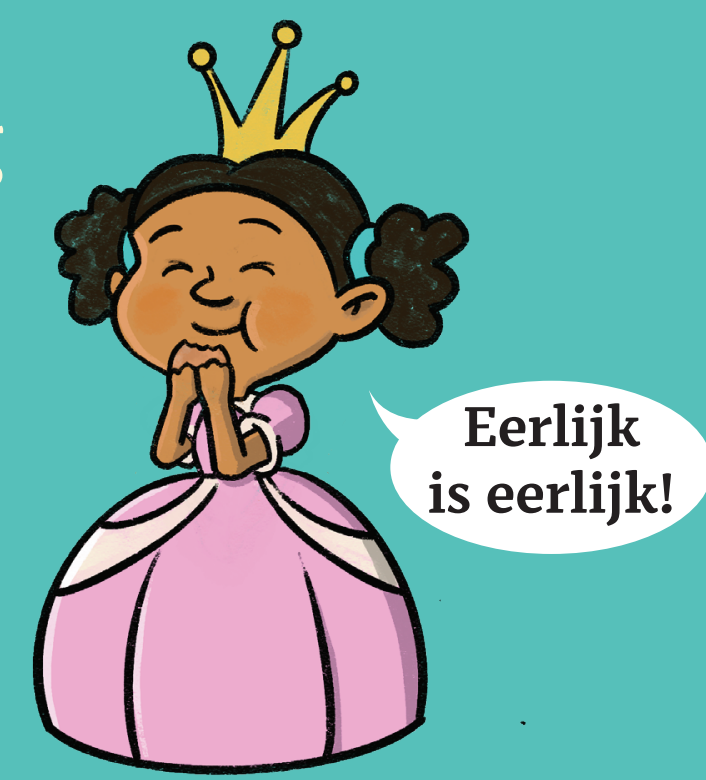


4 Geleidelijk paste tante Truus haar overtuiging aan dat Karin het meeste weet van dinosaurussen.

Eerst had tante Truus geen enkel idee. Na de Triceratops vraag vond tante Truus het waarschijnlijk dat Karin het meeste weet. En na de Stegosaurus vraag begon tante Truus weer wat meer te twijfelen.

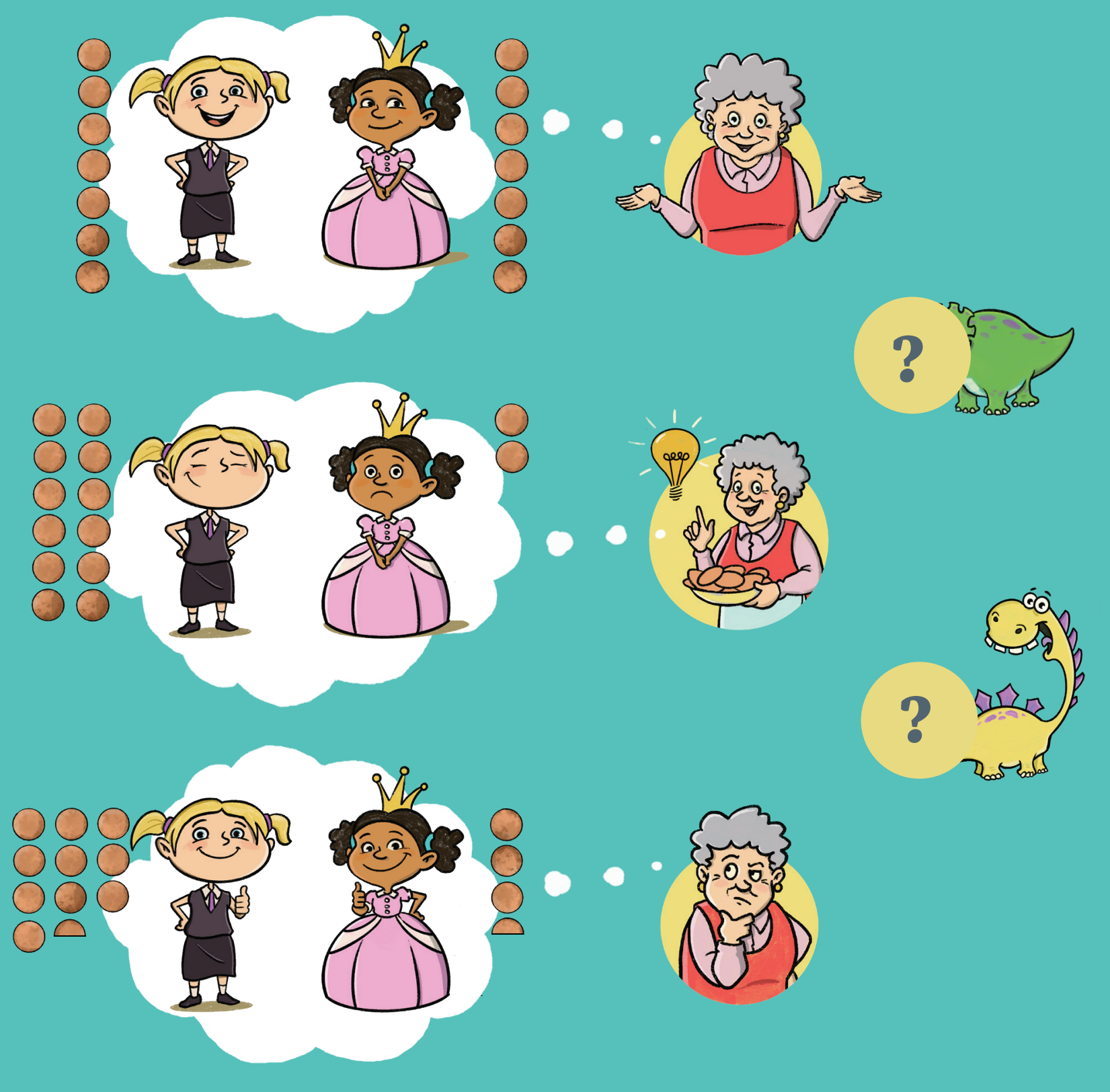


5 Karin deed het beter dan Marieke op de Triceratops vraag, maar Marieke deed het beter dan Karin op de Stegosaurus vraag.

Een ieder deed het beter dan de ander omdat het indrukwekkender is om het antwoord precies te weten dan om het ongeveer te weten.

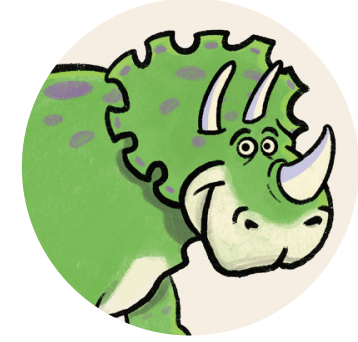

Precies weten

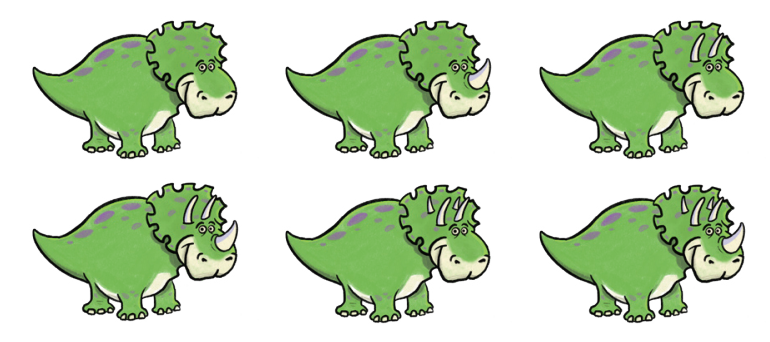

Ongeveer weten
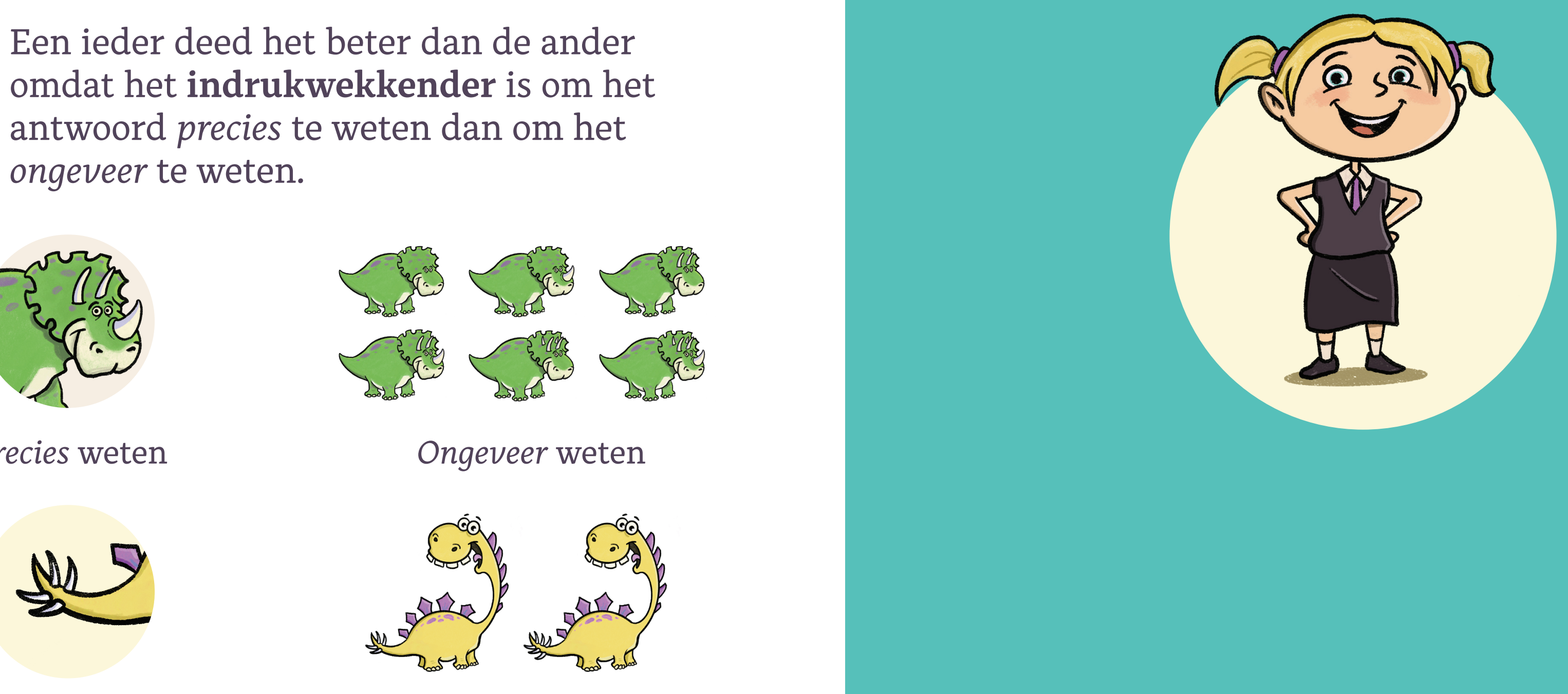


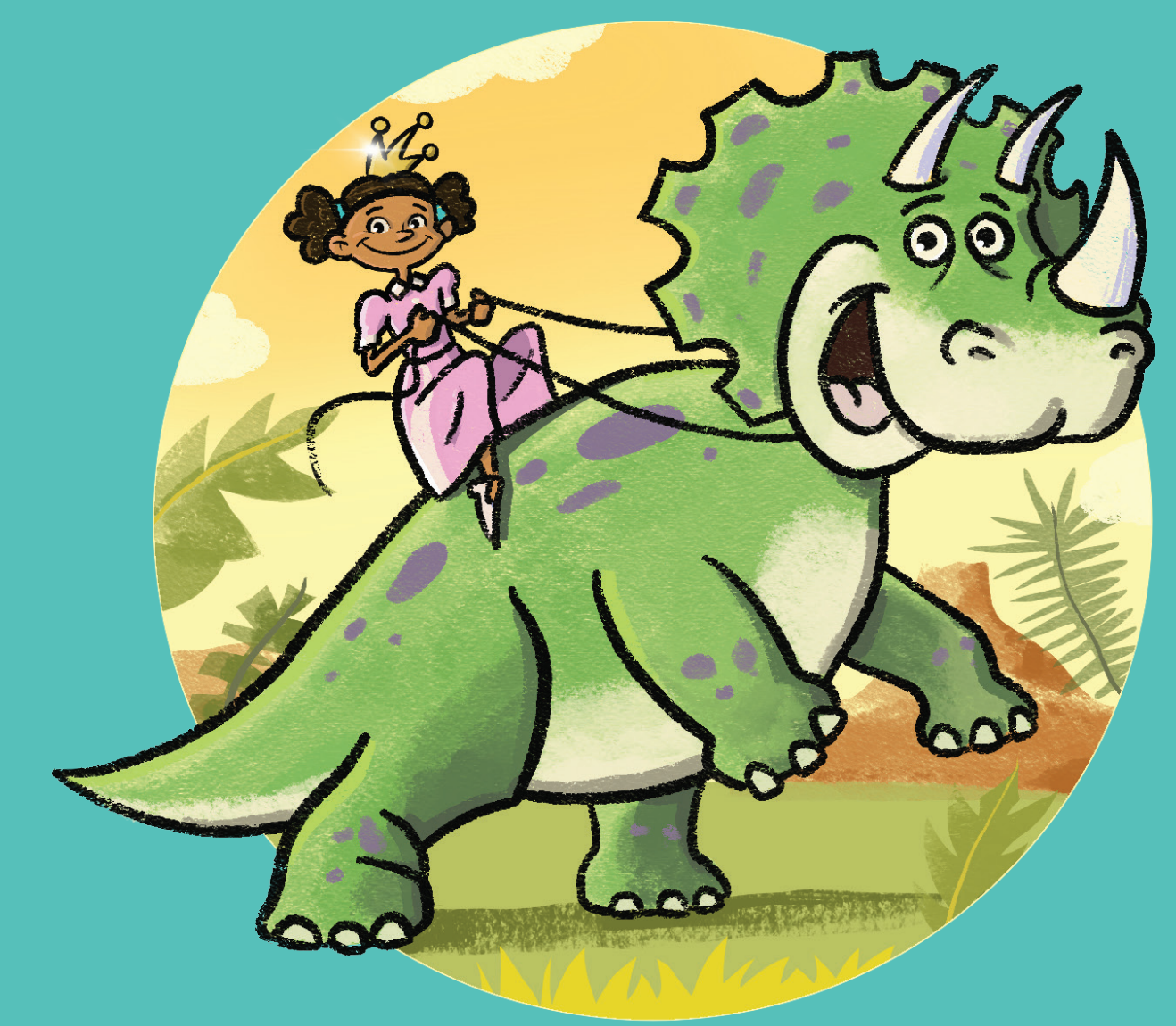

Peuters, studenten en wetenschappers kunnen JASP gebruiken voor praktische Bayesiaanse analyses. JASP is gratis te downloaden van jasp-stats.org.

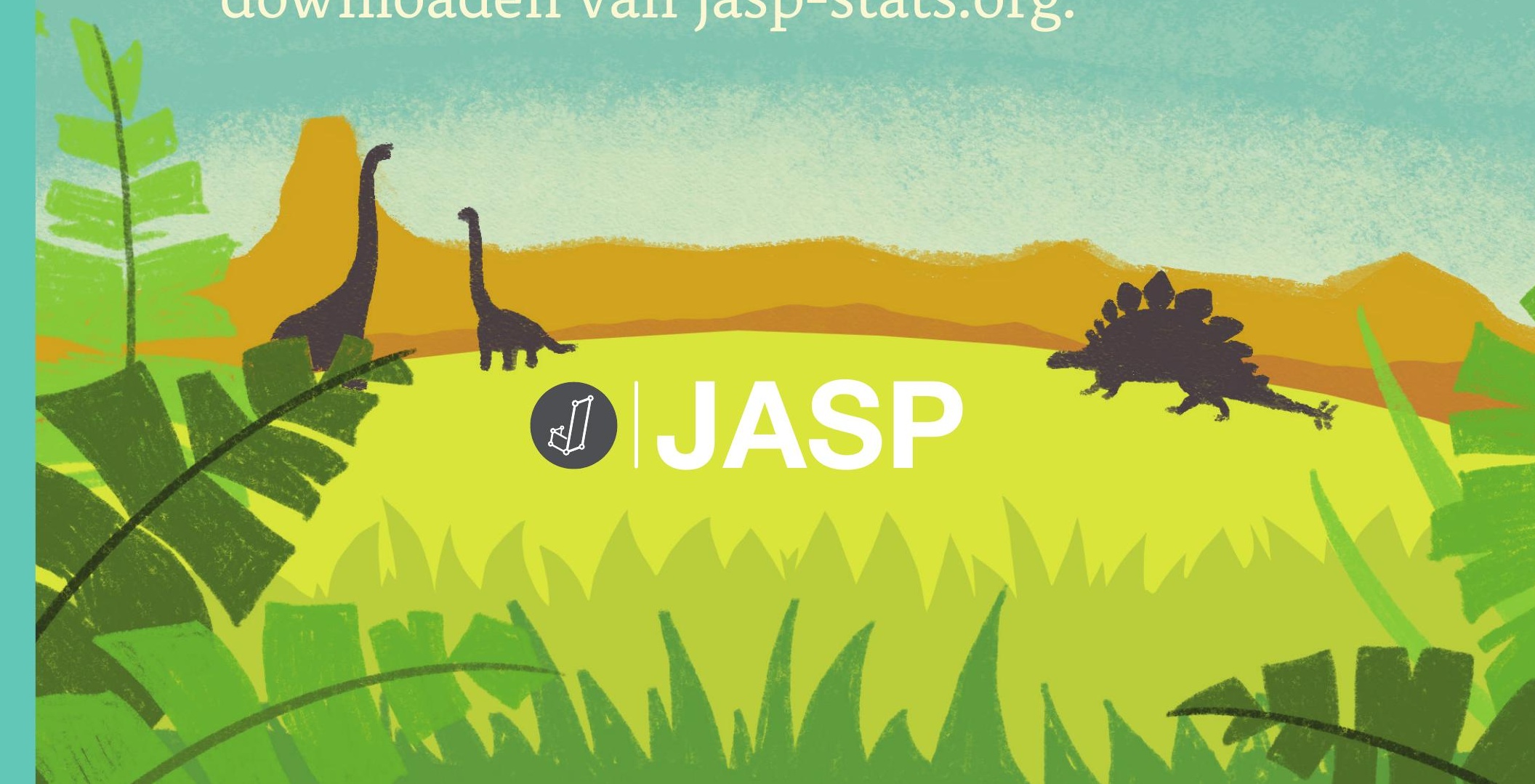




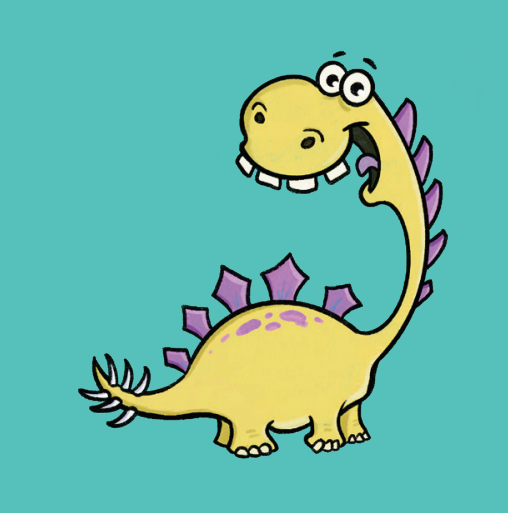

\section{Eric-Jan Wagenmakers}

Illustraties door Viktor Beekman

Grafische vormgeving door Johan van der Woude

() JASP | 2020 
Bayesiaans denken is eenvoudig, en peuters doen niet anders. Het leidende principe is ervaringsleren: hypotheses die de data goed voorspellen worden meer waarschijnlijk, en hypotheses die de data slecht voorspellen worden minder waarschijnlijk. Hypothese A is bijvoorbeeld "Om 6 uur 's ochtends liggen mijn ouders vaak nog te slapen" en hypothese B is "Om 6 uur 's ochtends zijn mijn ouders vaak al wakker." Als een peuter wakker wordt om 6 uur en merkt dat zijn ouders nog slapen dan verhoogt dit de waarschijnlijkheid van hypothese $A$ en verlaagt dit de waarschijnlijkheid van hypothese B. Gemakkelijk dus!

Ingewijden zullen opmerken dat onder de dekmantel van het dinosaurusverhaal concepten schuilgaan zoals het scheermes van Ockham, coherente aanpassing van kennis, en het kansbegrip als mate van redelijke overtuiging. Statistici herkennen het "prequential principle" van Phil Dawid. Peuters zijn allicht meer geboeid door de dinosaurussen.

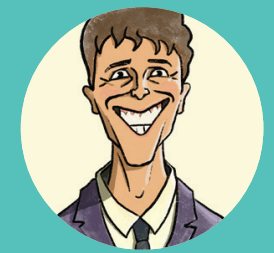

Eric-Jan Wagenmakers is hoogleraar aan de afdeling Psychologische Methodenleer van de Universiteit van Amsterdam. Hij is de oprichter van JASP (jasp-stats. org), een gratis en gebruikersvriendelijk programma voor zowel Bayesiaanse als niet-Bayesiaanse analyses.

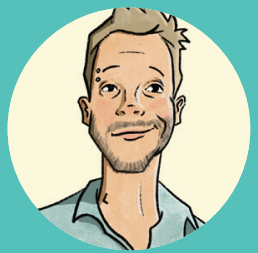

Viktor Beekman is een creatief ontwerper en illustrator uit Hilversum. Meer van zijn werk is te vinden op Instagram: @viktordepictor 